\title{
The use of bisphthalonitriles in the synthesis of side-strapped 1,11,15,25-tetrasubstituted phthalocyanines
}

\author{
Clifford C. Leznoff and David M. Drew
}

\begin{abstract}
Nucleophilic aromatic substitution reactions of 3-nitrophthalonitrile yield 3-hydroxyphthaionitrile and 3-neopentoxyphthalonitrile, the latter of which condensed to 1,8,15,22-tetraneopentoxyphthalocyanine as a mixture of isomers. Bisphthalonitriles such as 1,3-bis $\left(2^{\prime}, 3^{\prime}\right.$-dicyanophenoxy)-2,2-dipentylpropane, I,3-bis (2', $3^{\prime}$-dicyanophenoxy)-2,2diethylpropane, 1,3-bis ( $2^{\prime}, 3^{\prime}$-dicyanophenoxy)-2,2-dioctylpropane, and 1,3-bis ( $2^{\prime}, 3^{\prime}$-dicyanophenoxy)-2-methyl-2trityloxymethylpropane all gave bis-crown-like 1, II,15,25-tetrasubstituted phthalocyanines as pure compounds when treated with lithium octoxide in 1 -octanol at $196^{\circ} \mathrm{C}$. A host of nine other bisphthalonitriles including 1,5-bis $\left(2^{\prime}, 3^{\prime}\right.$-dicyanophenoxy)-3oxapentane, 1,1-bis $\left(2^{\prime}, 3^{\prime}\right.$-dicyanophenoxymethyl)cyclohexane, 1,2-bis $\left(2^{\prime}, 3^{\prime}\right.$-dicyanophenoxymethyl)benzene, and 2,5-bis (2',3'dicyanophenoxymethyl)furan did not dimerize to mononuclear phthalocynaines. The "gem dimethyl" effect was suggested as a reason for the successful macrocyclizations.
\end{abstract}

Key words: nucleophilic aromatic substitution, phthalonitriles, bisphthalonitriles, 1,11,15,25-tetrasubstituted phthalocyanines.

\begin{abstract}
Résumé : Les réactions de substitutions aromatiques nucléophiles du 3-nitrophtalonitrile conduisent au 3-hydroxyphtalonitrile et au 3-néopentoxyphtalonitrile; ce dernier se condense pour conduire à la 1,8,15,22-tétranéopentoxyphtalocyanine sous la forme d'un mélange d'isomères. Lorsqu'on soumet les bisphtalonitriles, tels que les 1,3-bis(2',3'-dicyanophénoxy)-2,2dipentylpropane, 1,3-bis(2',3'-dicyanophénoxy)-2,2-diéthylpropane, 1,3-bis(2',3'-dicyanophénoxy)-2,2-dioctylpropane et 1,3-bis(2',3'-dicyanophénoxy)-2-méthyl-2-trityloxyméthylpropane, à un traitement par de l'octylate de lithium en présence d'octan-1-ol à $196^{\circ} \mathrm{C}$ on obtient toujours des phtalocyanines $1,11,15,25$-tétrasubstituées à l'état pur qui ressemblent à des couronnes doubles. Neuf autres bisnaphtonitriles, y compris les 1,5-bis(2',3'-dicyanophénoxy)-3-oxapentane, 1,1-bis ( $2^{\prime}, 3^{\prime}$ dicyanophénoxyméthyl)cyclohexane, 1,2-bis ( $2^{\prime}, 3^{\prime}$-dicyanophénoxyméthyl)benzène et 2,5 -bis $\left(2^{\prime}, 3^{\prime}\right.$-dicyanophénoxyméthyl)furane, ne se dimérisent pas en phtalocyanines mononucléaires. L'effet «gem-diméthyle» a été suggéré pour expliquer le succès des macrocyclisations qui ont réussi.
\end{abstract}

Mots clés : substitution aromatique nucléophile, phtalonitriles, bisphtalonitriles, phtalocyanines 1,11,15,15-tétrasubstituées.

[Traduit par la rédaction]

\section{Introduction}

The synthesis of pure isomers of tetrasubstituted phthalocyanines $(\mathrm{Pc})$ having one substituent in each of the benzene rings remains a difficult problem (1). Single isomers of $2,9,16,23$ (2), 2,9,17,24- (3), and 1,8,15,22-tetrasubstituted phthalocyanines (4), and a 1,2-naphthalocyanine (5) have been prepared capitalizing on reactive substrates (2) or electronic (3) or steric constraints $(4,5)$ but methods towards the synthesis of pure $1,11,15,25$-tetrasubstituted phthalocyanines have been only briefly reported by us in a preliminary communication (6). Recently, some specific pure $\mathrm{Pc}$ isomers have been separated by chromatography (7). We decided upon a "constrained" approach towards the synthesis of phthalocyanines having substituents in the $1,11,15,25$ positions. If we could dimerize bisphthalonitriles with appropriate bridging groups, then $1,11,15,25$-tetrasubstituted phthalocyanines containing bridg-

C. C. Leznoff ${ }^{1}$ and D. M. Drew. Department of Chemistry, York University, North York (Toronto), ON M3J 1P3, Canada.

1 Author to whom correspondence may be addressed. Telephone: (416) 736-2100, ext. 33838. Fax: (416) 736-5936. E-mail: FS300067@SOL.YORKU.CA ing substituents (side straps) in the 1,25 and 11,15 positions would be obtained. The difficulty in this approach is the fact that polymerization would compete with dimerization. After exploring many different conditions we found that that condensation of bisphthalonitriles under high dilution at high temperatures for short reaction times led in some cases to the desired phthalocyanines as shown below.

\section{Results and discussion}

Nucleophilic aromatic substitution reactions on 3-nitrophthalonitrile (1) (9) are not all that common $(4,8,9)$ and hence we decided to examine some simple reactions of 1 . Thus treatment of 1 with $\mathrm{K}_{2} \mathrm{CO}_{3}$ and $\mathrm{NaNO}_{2}$ in DMSO at reflux for 0.5 $h$, as for the preparation of 4-hydroxyphthalonitrile (10), led to 3 -hydroxyphthalonitrile (2) in $43 \%$ yield. Similarly, treatment of 1 with neopentanol (2,2-dimethyl-1-propanol) and $\mathrm{K}_{2} \mathrm{CO}_{3}$ in DMSO at room temperature for 6 days gave 3-neopentoxyphthalonitrile in $63 \%$ yield. The long reaction times were necessary to drive the reaction to completion probably due to steric hindrance of the substitution at the 3-position $(4,8)$ and the bulky alcohol used. Conversion of 3 to its diiminoisoindoline 4 proceeded normally $(11,12)$. Condensation of 4 at $150^{\circ} \mathrm{C}$ in $2-N, N$-dimethylaminoethanol (DMAE) $(11,12)$ 
Scheme 1.<smiles>N#Cc1cccc(O)c1C#N</smiles>

2<smiles>N#Cc1cccc([N+](=O)[O-])c1C#N</smiles>

1

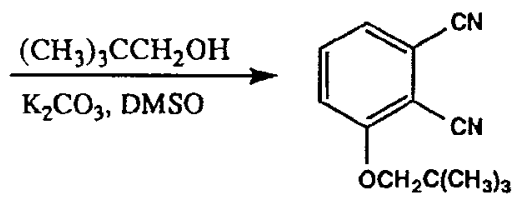

3<smiles>CCOc1cccc2c1C(=N)NC2=N</smiles>

4

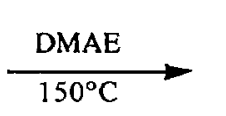

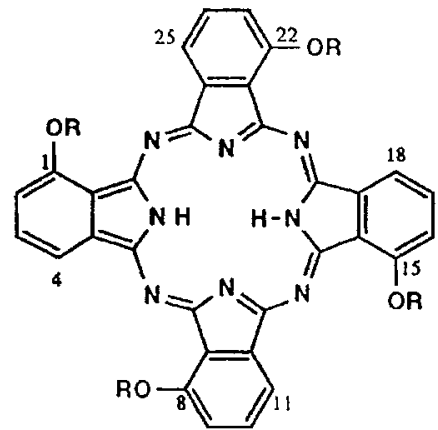

$5 \quad \mathrm{R}=\left(\mathrm{CH}_{3}\right)_{3} \mathrm{CCH}_{2} \mathrm{O}$

gave 1,8,15,22-tetraneopentoxyphthalocyanine (5) in $16 \%$ yield as a mixture with its $1,8,15,25,1,8,18,25$, and $1,11,15,25$ isomers (Scheme 1).

Having established that phthalocyanines containing bulky substituents at positions adjacent to the macrocyclic core are readily prepared, we directed our attention towards the preparation of bisphthalonitriles bridged at the 3-position, for eventual dimerization to $1,11,15,25$-tetrasubstituted phthalocyanines. Earlier, we had suggested (12) that $\beta$-hydrogens on substituents could lead to $\beta$-elimination reactions under the basic conditions of $\mathrm{Pc}$ formation and hence we concentrated our attention on bridging groups containing no hydrogens at the $\beta$-position, particularly $\beta, \beta$-dialkyl groups. Thus, treatment of 1 with a series of $\beta, \beta$-disubstituted-1,3-propanediols, such as the known 2-methyl-2-trityloxymethyl-1,3-propanediols (6) (12), the commercially available 2,2-diethyl-1,3propanediol (7), 2,2-dipentyl-1,3-propanediol (8), and 2,2dioctyl-1,3-propanediol (9), and $\mathrm{K}_{2} \mathrm{CO}_{3}$ in dimethyl sulfoxide (DMSO) at $20^{\circ} \mathrm{C}^{2}$ while evacuated $(4,6)$ gave the bisphthalonitriles $\mathbf{1 0 - 1 3}$ in $43-94 \%$ yields. Diols 8 and 9 were prepared by lithium aluminum hydride reduction of diethyl 2,2-dipentylmalonate (13) and diethyl 2,2-dioctylmalonate (14), respectively. Dimerization of $\mathbf{1 0 - 1 3}$ under high-dilution conditions with lithium octoxide in 1 -octanol at $196^{\circ} \mathrm{C}$ for $10 \mathrm{~min}$ gave the 1,25:11,15-bis(side-strapped) phthalocyanines 14-17 in 7$21 \%$ yields. Pcs 14,16 , and 17 were readily metallated to their phthalocyaninato zinc(II) compounds $\mathbf{1 8 - 2 0}$ in $90 \%$ yield by heating with zinc acetate in a 1:1 mixture of pyridine and $N, N$ -

2 Side-products at higher temperatures and shorter reaction times included 2 , etherols such as 3-(2', $3^{\prime}$-dicyanophenoxy-2,2diethylpropan-1-ol, and bis(2,3-dicyanophenyl)ether (BDPE), mp 223-226 $6^{\circ}$; FT-IR $\left(\mathrm{cm}^{-1}\right): 3087,3035,2238(\mathrm{C} \equiv \mathrm{N}), 1565$, $1461,1270,813$; ' $\mathrm{H}$ NMR (acetone- $\left.d_{6}\right) \delta: 702(\mathrm{~m}, 4 \mathrm{H}), 6.78(\mathrm{~d}$, $2 \mathrm{H}, J=8 \mathrm{~Hz}$ ); ${ }^{13} \mathrm{C}$ NMR (acetone- $\left.d_{6}\right) \delta: 158.29,136.95,131.18$, 124.76, 118.24, 115.81, 113.02, 108.87; El-MS for $\mathrm{C}_{16} \mathrm{H}_{6} \mathrm{~N}_{4} \mathrm{O}$, $\mathrm{m} / \mathrm{z}$ (relative intensity): $270\left(\mathrm{M}^{+}, 100\right) 242$ (13) 127 (10). dimethylformamide for $20 \mathrm{~h}$ at reflux conditions (Scheme 2). Attempts at cleavage of the side-strapped Pcs $14^{3}$ and 19 as examples, using $\mathrm{BBr}_{3}(15,16)$ as previously described for 2,9,16,23-tetraneopentoxyphthalocyanine (17), simply gave recovered starting materials, while cleavage with $\mathrm{AlI}_{3}$ (18) gave decomposition of the phthalocyanine macrocycle.

Phthalocyanines 14 and 18 existed as an unequal mixture of cis and trans isomers as shown by NMR spectroscopy while Pc 15 was too insoluble for useful studies. Indeed, the insolubility of $\mathbf{1 5}$ and the attendant difficulties of purification meant that satisfactory analysis could not be obtained for this compound, although we feel that confirmation of structure is on firm ground with a good HRMS (see Experimental). The problems of working with 15 in fact led to the design of Pcs 16 and 17 having larger alkyl chains generating soluble, more readily characterized Pcs. Pcs 16, 17, 18, and 19 were all sufficiently soluble for easy separation and study. In an attempt to obtain symmetrical hydroxymethyl substituents at the $\beta$-position and also to tie back the $\beta$-substituents into a ring system so that subsequent cleavage might proceed more readily, 5,5-dihydroxymethyl-2-phenyl-1,3-dioxane (21) (19) and 1,1-dihydroxymethylcyclohexane (22) (20) were treated as above, but over a $12-16$ day period, to give 5,5-bis $\left(2^{\prime}, 3^{\prime}\right.$-dicyanophenoxymethyl)-2-phenyl-1,3-dioxane (23) and 1,1-bis $\left(2^{\prime}, 3^{\prime}\right.$ (dicyanophenoxymethyl)cyclohexane (24) in 73 and $65 \%$ yields, respectively (Scheme 3). Neither 23 nor 24 could be induced to undergo formation of mononuclear phthalocyanines and it appeared that only polymeric pigments were formed.

In attempts to make a larger variety of side-strapped phthalocyanines, including those of crown ethers and benzylic ethers that could be more readily cleaved (4), we treated a host

\footnotetext{
3 The trityl groups in 14 were removed by $\mathrm{BBr}_{3}$ to give a mixture in $31 \%$ yield of the appropriate cis and trans diols, as a light blue solid; EI-MS for $\mathrm{C}_{42} \mathrm{H}_{34} \mathrm{~N}_{8} \mathrm{O}_{6}, \mathrm{~m} / \mathrm{z}$ (relative intensity): $746\left(\mathrm{M}^{+}\right.$, 100), $716(20), 355$ (18), 281 (22), 207 (37), 119 (39), 73 (42).
} 
Scheme 2.<smiles>[R]C([R7])(CO)CO[2H]</smiles><smiles>[R]C([R])(COc1cccc(C#N)c1C#N)C[C@H](C)COc1cccc(C#N)c1C#N</smiles>

$$
\begin{aligned}
& 6 \mathrm{R}=\mathrm{CH}_{3}, \mathrm{R}^{\prime}=\mathrm{CH}_{2} \mathrm{OTr} \\
& 7 \mathrm{R}=\mathbf{R}^{\prime}=\mathrm{C}_{2} \mathrm{H}_{5} \\
& 8 \mathrm{R}=\mathbf{R}^{\prime}=\mathrm{C}_{5} \mathrm{H}_{11} \\
& 9 \mathrm{R}=\mathbf{R}^{\prime}=\mathrm{C}_{8} \mathrm{H}_{17}
\end{aligned}
$$$$
10 \mathrm{R}=\mathrm{CH}_{3}, \mathrm{R}^{\prime}=\mathrm{CH}_{2} \mathrm{OTr}
$$$$
11 \mathrm{R}=\mathrm{R}^{\prime}=\mathrm{C}_{2} \mathrm{H}_{5}
$$$$
12 \mathrm{R}=\mathrm{R}^{\prime}=\mathrm{C}_{5} \mathrm{H}_{11}
$$$$
13 \mathrm{R}=\mathrm{R}^{\prime}=\mathrm{C}_{8} \mathrm{H}_{17}
$$

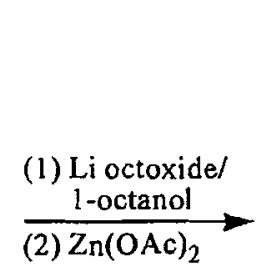

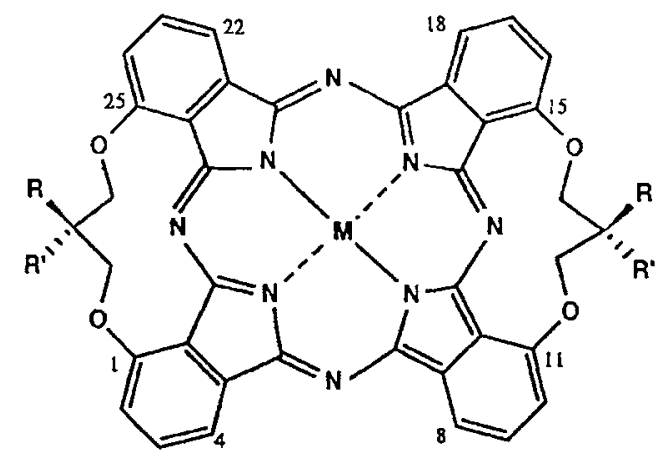

$$
\begin{aligned}
& 14 \mathrm{R}=\mathrm{CH}_{3}, \mathrm{R}^{\prime}=\mathrm{CH}_{2} \mathrm{OTr}, \mathrm{M}=\mathrm{H}_{2},+ \text { trans } \\
& 15 \mathrm{R}=\mathrm{R}^{\prime}=\mathrm{C}_{2} \mathrm{H}_{5}, \mathrm{M}=\mathrm{H}_{2} \\
& 16 \mathrm{R}=\mathrm{R}^{\prime}=\mathrm{C}_{5} \mathrm{H}_{11}, \mathrm{M}=\mathrm{H}_{2} \\
& 17 \mathrm{R}=\mathrm{R}^{\prime}=\mathrm{C}_{8} \mathrm{H}_{17}, \mathrm{M}=\mathrm{H}_{2} \\
& 18 \mathrm{R}=\mathrm{CH}_{3}, \mathrm{R}^{\prime}=\mathrm{CH}_{2} \mathrm{OTr}, \mathrm{M}=\mathrm{Zn},+ \text { trans } \\
& 19 \mathrm{R}=\mathrm{R}^{\prime}=\mathrm{C}_{5} \mathrm{H}_{11}, \mathrm{M}=\mathrm{Zn} \\
& 20 \mathrm{R}=\mathrm{R}^{\prime}=\mathrm{C}_{8} \mathrm{H}_{17}, M=\mathrm{Zn}
\end{aligned}
$$

Scheme 3.
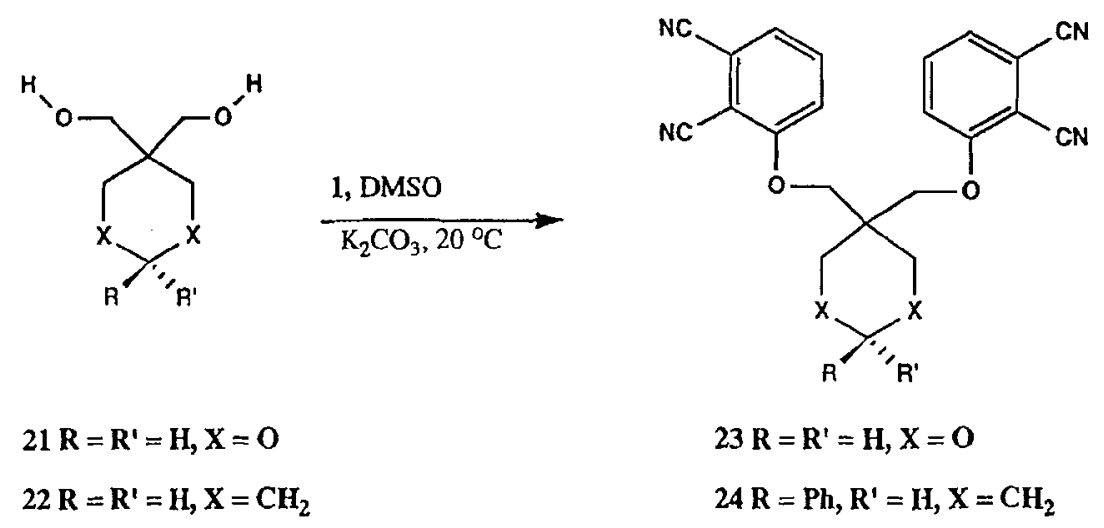

$$
22 \mathbf{R}=\mathbf{R}^{\prime}=\mathrm{H}, \mathrm{X}=\mathrm{CH}_{2}
$$$$
23 R=R^{\prime}=H, X=O
$$$$
24 \mathbf{R}=\mathbf{P h}, \mathbf{R}^{\prime}=\mathrm{I} \mathbf{H}, \mathrm{X}=\mathrm{CH}_{2}
$$ 
Scheme 4.<smiles>OCPCO</smiles><smiles>N#Cc1cccc(OCPCOc2cccc(C#N)c2C#N)c1C#N</smiles>

$25 \mathrm{R}=-\mathrm{CH}_{2} \mathrm{OCH}_{2}-$

$26 \mathrm{R}=$<smiles>Cc1ccccc1C</smiles>

$27 \mathrm{R}=$<smiles>Cc1ccccc1-c1ccccc1C</smiles>

$28 \mathbf{R}=$<smiles>Cc1cc(C)cc(Br)c1</smiles>

$29 \mathrm{R}=$<smiles>Cc1ccc(C)o1</smiles>

$30 \mathbf{R}=$<smiles>CC1CCC(C)O1</smiles>

of known symmetrical diols such as diethylene glycol (25), 1,2-dihydroxymethylbenzene (26), 2,2'-bis(hydroxymethyl)biphenyl (27) (21), 5-tert-butyl-1,3-dihydroxymethylbenzene (28) (22), 2.5-dihydroxymethylfuran (29), and cis2,5-bis(hydroxymethyl)tetrahydrofuran (30) (23) as before to give the new bisphthalonitriles 31-37 in $19-56 \%$ yields. Unfortunately, none of 31-37 cyclized to bis side-strapped phthalocyanines under our standard conditions described above.

It is curious that among the 13 symmetrical bisphthalonitriles prepared for this study, only 10-13 underwent dimerization to mononuclear phthalocyanines. With hindsight it is possible to see that perhaps the "gem dimethyl (Thorpe-Ingold) effect " $(24-26)$ is operating here as only 10-13 have noncyclic $\beta, \beta$-dialkyl substituents. The gem dimethyl effect was originally promulgated to explain favoured cyclization reactions in five- to seven-membered rings containing $\beta, \beta$-dimethyl substituents, but was later expanded to macrocyclic ring systems (27).

\section{Spectroscopic and physical properties}

It is well known that electron-donating substituents at the 1, 4, $8,11,15,18,22$, and 25 positions of the phthalocyanine nucleus (cf. 5) result in an enhanced bathochromic shift of the Q-band in their UV-VIS spectra $(1,7,28,29)$, when compared to similar substitution at the $2,3,9,10,16,17,23$, and 24 positions of the Pc nucleus. Thus, 5 shows a typical $\lambda_{\max }$ at $726 \mathrm{~nm}$. Surprisingly, 14-17 exhibit $\lambda_{\max }$ values at 708-711 nm (Fig. 1) rather than the values at $\sim 730 \mathrm{~nm}$ exhibited in related pure 1,8,15,22-alkoxy-substituted Pcs (4, 7) and another pure $1,11,15,25$-alkoxy-substituted Pc (7). We believe that the
$31 \mathrm{R}=-\mathrm{CH}_{2} \mathrm{OCH}_{2}$

$32 R=R$ in 26

$33 \mathbf{R}=\mathbf{R}$ in 27

$34 R=R$ in 28

$35 \mathbf{R}=\mathbf{R}$ in 29

$36 \mathbf{R}=\mathbf{R}$ in 30 nature of the alkoxy substituent constrained in a ring system may cause the lone pair of electrons to lie partially out of conjugation with the benzo groups. Cook et al. (29) noticed that in one of their octaalkoxyphthalocyanines containing additional chloro substituents at the $2,3,9,10,16,17,23$, and 24 positions, the $\lambda_{\max }$ is shifted hypsochromically by about $20 \mathrm{~nm}$ relative to other octaalkoxyphthalocyanines, and this latter example could be regarded as a partially constrained phthalocyanine. As usual, the Pc zinc(II) derivatives 18-20 (Table 2, Fig. 2) exhibit $\lambda_{\max }$ values of the Q-band having a hypsochromic shift of $20-25 \mathrm{~nm}$ compared to their metal-free counterparts.

The UV-VIS spectrum of 19 (Fig. 2) showed a spectral profile consistent with a PcM of $D_{4 h}$ symmetry in which a single intense Q-band absorption is found. The single Q-band absorption in the UV-VIS spectrum (suggesting a PcM with $D_{4 \mathrm{~h}}$ symmetry) conflicts somewhat with the actual geometry of 19 in which the 1,25:11,15-bis(side-strapped) PcZn 18 is, on a macromolecular scale, of $D_{2 h}$ symmetry. This observation strongly suggests that the peripheral sidestrap substituents do not affect, or only very weakly affect, the Pc macrocycle molecular orbitals involved in the Q-band HOMO-LUMO electron transition. These results are markedly different from other $D_{2 \mathrm{~h}}$ "opposite" Pcs in which Q-band splitting for metallophthalocyanines is observed $(30,31)$.

The ${ }^{1} \mathrm{H}$ NMR of ZnPc 18 taken in THF- $d_{8}$ clearly showed the ABX splitting pattern generated by the aromatic hydrogens of the Pc macrocycle (doublet-triplet-doublet at 9.02 , 7.99, and $7.68 \mathrm{ppm}$, respectively). As for metal-free 14, the presence of two possible side strap isomers generated two multiplets at 5.38 and 5.17 ppm for the methylene $\mathrm{CH}_{2}$ hydro- 
Fig. 1. The electronic spectrum for metal-free bis side-strapped Pc (16).

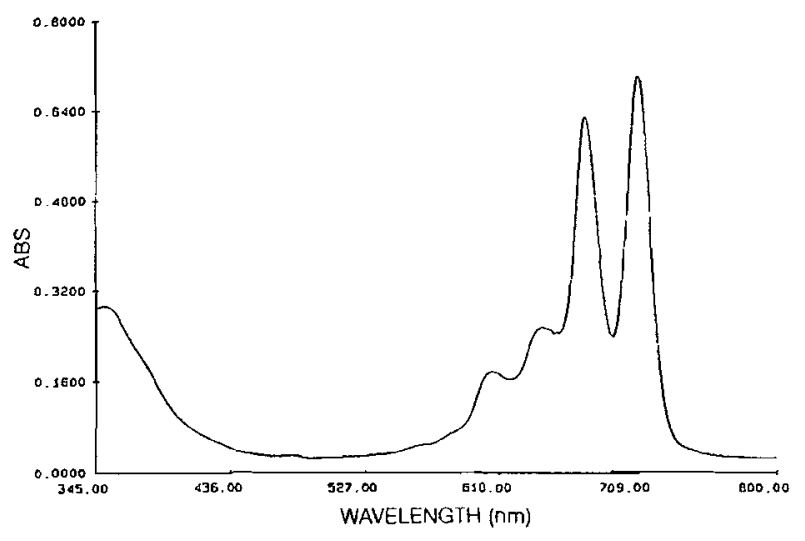

Fig. 2. The electronic spectrum of bis side-strapped zinc (II) Pc (19).

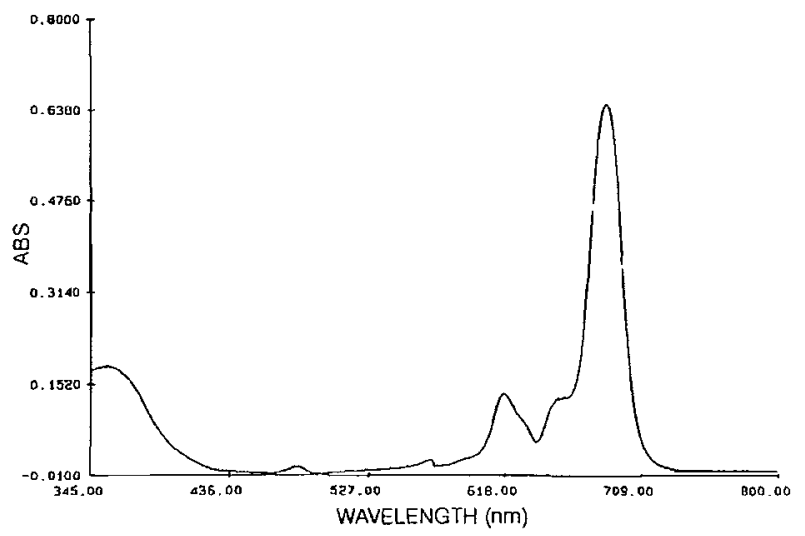

gens of the side-straps in addition to two pairs of singlets that arise from the 2'-methylene $\mathrm{CH}_{2}$-OTr and 2'-methyl $\mathrm{CH}_{3}$ hydrogens at $3.66,3.64$ and $1.65,1.62 \mathrm{ppm}$, respectively.

The NMR spectrum of 17 was examined in the most detail as it was the most soluble of the bis side-strapped Pcs. The ${ }^{1} \mathrm{H}$ NMR spectrum of 17 in benzene- $d_{6}$ clearly showed the doublet-triplet-doublet signals arising from the ABX-spin-type aromatic hydrogens, and a singlet signal corresponding to the $\mathrm{CH}_{2}$ hydrogens of the side straps. The internal $\mathrm{N}-\mathrm{H}$ protons were evident as a broad proton signal shifted upfield to -6 ppm (6). Such a large upfield 'H NMR chemical shift of the N$\mathrm{H}$ hydrogens is typical for Pcs at high concentration or for cofacial binuclear Pcs $(12,32)$. This upfield chemical shift is a reflection of the strong cone of aromaticity generated by the ring current of the Pc macrocycle (32). At high Pc concentrations, or for Pcs that have a tendency toward cofacial $\pi-\pi$ interaction (i.e., Pc aggregates, cofacial binuclear Pcs), the shielding imparted by the Pc macrocycle has profound effects upon the chemical shifts of hydrogens of proximal Pc neighbours.

These shielding effects experienced by the aromatic, sidestrap, and internal hydrogens were explored by the acquisition of ${ }^{1} \mathrm{H}$ NMR spectra at varying concentrations of 17 in THF- $d_{8}$ (Table 1, Fig. 3 and 4). These data indicate that as the Pc solution concentration increases, Pc aggregation (or $\pi-\pi$ stacking)
Table 1. 'H NMR dilution shifts (ppm) of aromatic, side-strap, and internal hydrogens for $P_{C} 17$.

\begin{tabular}{|c|c|c|c|c|c|c|}
\hline $\begin{array}{l}17 \\
(\mathrm{~mol} / \mathrm{L})\end{array}$ & $\begin{array}{l}-\log \\
17\end{array}$ & $\begin{array}{l}\text { Aryl } \\
\mathrm{H}=\mathrm{a}\end{array}$ & $\begin{array}{l}\text { Aryl } \\
\text { H-b }\end{array}$ & $\begin{array}{l}\text { Aryl } \\
\text { H-c }\end{array}$ & $\begin{array}{l}\text { Strap } \\
\mathrm{CH}_{2}\end{array}$ & $\mathrm{~N}-\mathrm{H}$ \\
\hline 0.0050 & 2.301 & 7.75 & 7.27 & 6.83 & 4.32 & -5.79 \\
\hline 0.0025 & 2.602 & 7.91 & 7.39 & 6.96 & 4.45 & -5.44 \\
\hline 0.0005 & 3.301 & 8.32 & 7.67 & 7.25 & 4.74 & -4.34 \\
\hline
\end{tabular}

occurs, and results in shifts of Pc macrocycle (and side-strap) hydrogen signals to higher field. The shielding effects imparted by the $\mathrm{Pc}$ macrocycle affect the internal N-H hydrogens, the aromatic hydrogens, and the side-strap methylene $\left(\mathrm{CH}_{2}\right)$ hydrogens to varying degrees. For instance, the internal $\mathrm{N}-\mathrm{H}$ hydrogens show the largest changes in chemical shift $(\Delta \delta$ $=1.45 \mathrm{ppm}$ ), whereas the change in chemical shift of the sidestrap hydrogens is smaller $(\Delta \delta=0.41 \mathrm{ppm})$. It appears that, in general, the hydrogen atoms closest to the core of the phthalocyanine macrocycle are most strongly influenced by the cone of aromaticity and $\pi-\pi$ stacking shielding effects. This information can be used in assigning the signals observed in the ${ }^{1} \mathrm{H}$ NMR spectrum to the three types of $\mathrm{Pc}$ ring hydrogens. It would seem plausible that the aromatic hydrogen experiencing the greatest change in chemical shift as a result of changing the Pc concentration would be the aromatic hydrogen closest to the Pc core. In Pc isomers such as 17, these would be the hydrogens at the $4,8,18$, and 22 positions of the macrocycle and would be represented by one of the two doublet signals observed in the aromatic region of the ${ }^{1} \mathrm{H}$ NMR spectrum. The furthest downfield doublet signal (i.e., that closest to $8 \mathrm{ppm}$ ) exhibited the largest change of chemical shift $(\Delta \delta=0.56 \mathrm{ppm})$ relative to the doublet found near $7 \mathrm{ppm}(\Delta \delta=0.42 \mathrm{ppm})$. Even though there was only a one order of magnitude change in the concentration of Pc 17, the data obtained from this experiment suggest that the 4-, 8-, 18-, and 22-position hydrogens can be assigned to this most downfield doublet signal $(\mathrm{H}-$ a in Fig. 3). This allowed an assignment of the highest field aromatic doublet signal (ca. 7 ppm) to the hydrogens at the 2 , 10,16 , and 24 positions (H-c, i.e., adjacent to the side strap) and, intuitively, the triplet signal (ca. $7.5 \mathrm{ppm}$ ) to the hydrogens at the $2,9,16$, and 23 positions of the Pc macrocycle. These hydrogen assignments were confirmed upon acquisition of a NOESY-NMR spectrum of 17 . Through-space NOE effects were observed between the side-strap $\mathrm{CH}_{2}$ and macrocycle $\mathrm{H}-\mathrm{c}$ hydrogens (i.e., the hydrogens in the position ortho to the side-strap), further validating the $\mathrm{Pc}$ ring hydrogen assignments determined from the ${ }^{1} \mathrm{H}$ NMR dilution shift experiment.

All new phthalocyanines and phthalonitriles exhibited parent ions in their FAB or EI mass spectra. IR data and good elemental analysis were consistent with the assigned structures. The directed syntheses of phthalocyanines having the unique substitution pattern at the $1,11,15,25$ positions have been demonstrated by constraining the substitution pattern with bridges at the 1,25 and 1,11 positions.

\section{Experimental}

All organic solvents were dried by appropriate methods and distilled before use. All reagents were freshly distilled, or 
Fig. 3. 'H NMR dilution shifts of aromatic, side-strap, and internal hydrogens for Pc 17 taken in THF$d_{8}$.

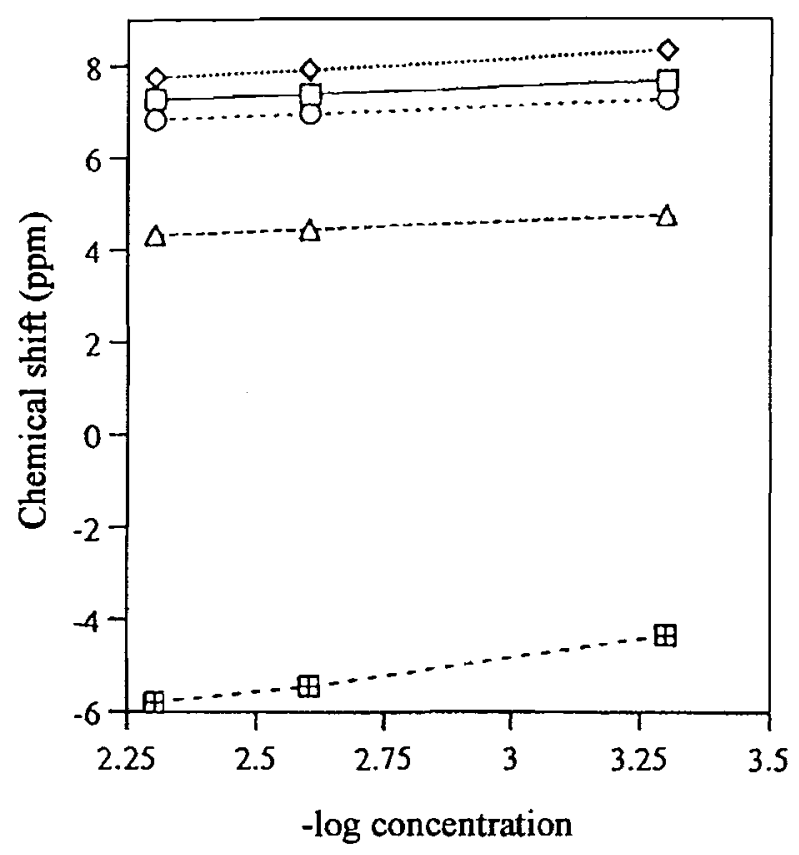

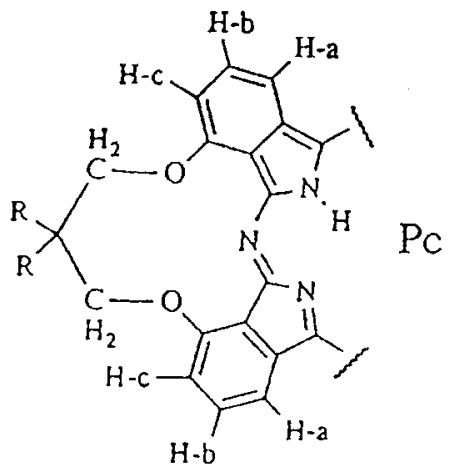

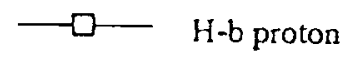

H-a proton

$\cdots \mathrm{O} \cdots \mathrm{H}-\mathrm{c}$ proton

$---1-\cdots-$ Strap protons

- - -

Fig. 4. The 'H NMR spectrum of the downfield region of $P c 17$ at $2.5 \times 10^{-4} \mathrm{M}$ in THF.

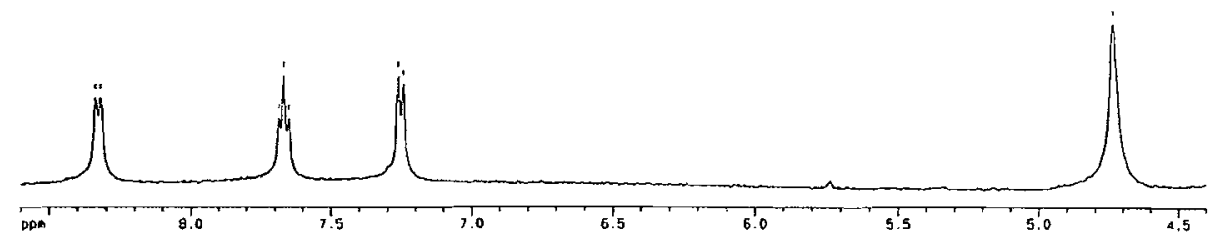

were recrystallized and then dried under reduced pressure, before use. Anhydrous potassium carbonate $\left(\mathrm{K}_{2} \mathrm{CO}_{3}\right)$ was finely ground, oven dried at $250^{\circ} \mathrm{C}$ for $36 \mathrm{~h}$, and then stored in sealed vials. Unless otherwise noted, magnetic stirring methods under an inert atmosphere (Matheson High Purity argon) were utilized during distillation or reaction processes, and round-bottom glass vessels chosen such that the quantity of reagents and solvent did not exceed half of the available volume. Water-cooled condensers were used if reaction processes were held near, or at, reflux conditions. Melting points were determined using a Kofler hot-stage melting point apparatus and are reported uncorrected. Infrared spectroscopy was performed on either a Pye Unicam SP3-200 or a Perkin Elmer 1310 infrared spectrophotometer and FTIR spectroscopy was performed on a Unicam Mattson 3000 FTIR spectrometer using samples prepared as $\mathrm{KBr}$ discs unless otherwise noted. Mass spectral analyses were performed by Dr. B. Khouw (York University, North York, Ontario, Canada), Dr. R. Smith (McMaster University, Hamilton, Ontario, Canada), and Dr. R. N. Cerny (Midwest Center for Mass Spectrometry, University of Nebraska-Lincoln, Lincoln, Nebraska, U.S.A.). HRMS were performed by Dr. R. Smith (McMaster University,
Hamilton, Ontario, Canada). Nuclear magnetic resonance (NMR) spectroscopy was performed at 295-300 K unless otherwise noted, using either a Bruker Aspect AM3000 or a Bruker ARX 400 high-field Fourier Transform instrument. Chemical shifts are reported in parts per million relative to a tetramethylsilane (TMS) internal standard. Splitting patterns of proton resonances are described as singlets (s), doublets (d), triplets (t), quartets $(q)$, doublets of doublets (dd), multiplets $(\mathrm{m})$, or as broad signals (br). Coupling constants for signals other than singlets and multiplets are reported in hertz. ${ }^{13} \mathrm{C}$ NMR resonances are reported as the proton-decoupled chemical shifts. In addition to one-dimensional (ID) ' $\mathrm{H}$ NMR and ${ }^{13} \mathrm{C}$ NMR, compounds requiring absolute structure determination were elucidated using combinations of $2 \mathrm{D}{ }^{\prime} \mathrm{H}$ NMR (COSY and NOESY) and 2D carbon-proton (XH) correlations.

\section{3-Hydroxyphthalonitrile (2)}

In a manner similar to that previously described in the preparation of 4-hydroxyphthalonitrile $(10), 865 \mathrm{mg}$ (5.00 mmol) of 3-nitrophthalonitrile $(1)(8,9)$ was dissolved in $5 \mathrm{~mL}$ of DMSO. $\mathrm{K}_{2} \mathrm{CO}_{3}(760 \mathrm{mg}, 5.51 \mathrm{mmol})$ and $\mathrm{NaNO}_{2}(345 \mathrm{mg}$, 
$5.00 \mathrm{mmol}$ ) were added and the mixture heated at reflux for 30 min. After cooling, the reaction mixture was diluted with 20 $\mathrm{mL}$ of $\mathrm{H}_{2} \mathrm{O}$, and the mixture acidified to $\mathrm{pH} 3$ with $\mathrm{HCl}$ and then centrifuged. The pellet was collected, resuspended in distilled water, homogenized by sonication, and again centrifuged. The supernatant liquid was discarded and the residue washed with methanol. The highly insoluble orange crude product was purified by column chromatography, using silica gel as the adsorbent and acetone as the eluting solvent. Evaporation of the solvent under reduced pressure gave a yellow solid that was recrystallized from glacial acetic acid to give $312 \mathrm{mg}(43 \%)$ of 2 as an amorphous pale yellow solid (TLC: $\left.10 \% \mathrm{CH}_{3} \mathrm{CN}-\mathrm{Bz}, R_{\mathrm{f}}=0.03\right)$, mp $233-235^{\circ} \mathrm{C}$; FT-IR $\left(\mathrm{cm}^{-1}\right)$ : $3228 \mathrm{br}(\mathrm{O}-\mathrm{H}), 3072,2255(\mathrm{C} \equiv \mathrm{N}), 2230(\mathrm{C} \equiv \mathrm{N}), 1584,1467$, $1316,975,807$; ' $\mathrm{H}$ NMR (DMSO- $\left.d_{6}\right) \delta: 7.62(\mathrm{t}, 1 \mathrm{H}, J=8 \mathrm{~Hz}$ ), $7.39(\mathrm{~d}, 1 \mathrm{H}, J=8 \mathrm{~Hz}), 7.29(\mathrm{~d}, 1 \mathrm{H}, J=8 \mathrm{~Hz}) ;{ }^{13} \mathrm{C} \mathrm{NMR}$ $\left(\mathrm{DMSO}-d_{6}\right) \delta: 162.42,135.09,123.75,122.08,116.16$, $114.75,114.50,100.68$; EI-MS $m / z(\%) ; 144\left(\mathrm{M}^{+}, 100\right), 116$ (85), 89 (12). Anal. Calcd. for $\mathrm{C}_{8} \mathrm{H}_{4} \mathrm{~N}_{2} \mathrm{O}: \mathrm{C} 66.67, \mathrm{H} 2.78, \mathrm{~N}$ 19.44; found: C 66.77, H 2.95, N 18.76.

\section{3-Neopentoxyphthalonitrile (3)}

Compound 3 was prepared in similar fashion to 4-neopentoxy-

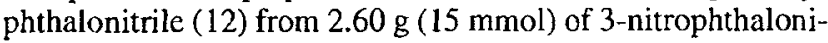
trile (1), $2.65 \mathrm{~g}$ (30 mmol) of neopentanol (3,3-dimethyl-1-

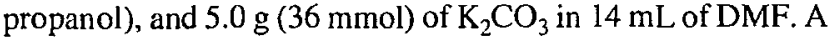
drying tube was used to maintain anhydrous conditions over the course of the 6 day reaction period required for complete consumption of 1 . The reaction mixture was poured into 100 $\mathrm{mL}$ of ice-cooled water and the organic products extracted with $3 \times 30 \mathrm{~mL}$ of EtOAc. The EtOAc extracts were combined, washed once with $70 \mathrm{~mL}$ of cold water, once with $10 \mathrm{~mL}$ of brine, and then dried over $\mathrm{MgSO}_{4}$. The drying agent was removed by filtration and the filtrate evaporated under reduced pressure to give $2.88 \mathrm{~g}$ of a crude product. The crude product was purified by column chromatography using $20 \%$ EtOAc petroleum ether as the eluting solvent and then by recrystallization from EtOAc-hexane to give $1.77 \mathrm{~g}$ of white crystalline 3 (mp $120-121.5^{\circ} \mathrm{C}$ ). A second crop of 3 was obtained from the mother liquor by addition of hexane followed by cooling to $5^{\circ} \mathrm{C}\left(0.24 \mathrm{~g}, \mathrm{mp} 119-120.5^{\circ} \mathrm{C}\right)$. The combined yield of 3 was $2.01 \mathrm{~g}(62.6 \%)$ (TLC: $20 \%$ EtOAc - petroleum ether, $R_{\mathrm{f}}=$ $0.30) ; \operatorname{IR}\left(\mathrm{cm}^{-1}\right): 3080,2950,2220(\mathrm{C} \equiv \mathrm{N}), 1580,1470,1300$, $1055(\mathrm{C}-\mathrm{O}), 790 ;{ }^{1} \mathrm{H}$ NMR $\left(\mathrm{CDCl}_{3}\right) \delta: 7.61(\mathrm{t}, l \mathrm{H}, J=8 \mathrm{~Hz})$, $7.33(\mathrm{~d}, 1 \mathrm{H}, J=8 \mathrm{~Hz}), 7.20(\mathrm{~d}, 1 \mathrm{H}, J=8 \mathrm{~Hz}), 3.74(\mathrm{~s}, 2 \mathrm{H}), 1.10$ $(\mathrm{s}, 9 \mathrm{H}) ;{ }^{13} \mathrm{C} \mathrm{NMR}\left(\mathrm{CDCl}_{3}\right) \delta: 161.72,134.49,124.84,116.87$, $116.81,115.34,112.87,104.94,79.51,32.05,26.33$; EI-MS $m / z(\%): 214\left(\mathrm{M}^{+}, 5.6\right), 199(12.5), 116(5.3), 71(100), 43$ (84). Anal. calcd. for $\mathrm{C}_{13} \mathrm{H}_{14} \mathrm{~N}_{2} \mathrm{O}: \mathrm{C} 72.87, \mathrm{H} 6.59, \mathrm{~N} 13.07$; found: $\mathrm{C} 73.20, \mathrm{H} 6.60, \mathrm{~N} 13.23$.

\section{4-Neopentoxy-1,3-diiminoisoindoline (4)}

Sodium methoxide was prepared from methanol $(25 \mathrm{~mL})$ and cleaned sodium metal (35 $\mathrm{mg}, 1.5 \mathrm{mmol}$ ). When methoxide formation was complete, $374.5 \mathrm{mg}(1.750 \mathrm{mmol})$ of 3 was added, the mixture heated to reflux, and gaseous $\mathrm{NH}_{3}$ bubbled through the solution. After $4.5 \mathrm{~h}$ of $\mathrm{NH}_{3}$ addition the solution colour changed from colourless to light yellow. A small aliquot of the solution was removed and the solvent evaporated under reduced pressure. The absence of a $C \equiv N$ stretch in the IR spectrum of this sample indicated that the reaction was complete. The reaction mixture was cooled to room temperature (RT) and concentrated to dryness under reduced pressure to give $467.1 \mathrm{mg}$ of crude 4 (TLC: $20 \%$ EtOAc - petroleum ether, $R_{\mathrm{f}}=0.01$ ). The yellowish crude product was not further purified and was used immediately in the preparation of $\mathrm{PcH}_{2}$ 5; IR $\left(\mathrm{cm}^{-1}\right)$ : 3460-3150br, 3320, 2980, 1605, 1480, 1260, 1055 .

\section{1,8,15,22-Tetraneopentoxyphthalocyanine (5)}

A solution of $467 \mathrm{mg}(1.75 \mathrm{mmol})$ of diiminoisoindoline 4 in 3 $\mathrm{mL}$ of $2-N, N$-dimethylaminoethanol (DMAE) was heated at $150^{\circ} \mathrm{C}$ (silicon oil bath) for $36 \mathrm{~h}$. The mixture was cooled to $\mathrm{RT}$ and the dark green-black slurry poured into $15 \mathrm{~mL}$ of cold water. Cold methanol $(30 \mathrm{~mL})$ was added, the mixture homogenized, and the fine precipitate centrifuged and collected in six fractions. The supernatant liquid from each fraction was discarded, and the pellets were resuspended in $5 \mathrm{~mL}$ of methanol and centrifuged. This centrifugation procedure was repeated until the supernatant liquid was almost colourless (four cycles). The pellets were combined to give $148 \mathrm{mg}$ of crude material that was purified by flash chromatography using toluene as the eluting solvent. The first product eluted was concentrated under reduced pressure to give $58.6 \mathrm{mg}$ (16\%) of $\mathrm{PcH}_{2} 5$ as a dark blue, shining solid (TLC: $2 \% 2$-methoxyethanol-toluene, $R_{\mathrm{f}}=0.70$ ), $\mathrm{mp}>325^{\circ} \mathrm{C}$; UV-VIS (THF) $\lambda_{\max }$ $(\mathrm{nm}): 318,354,630,664,696,726 ; \mathrm{IR}\left(\mathrm{cm}^{-1}\right): 3280(\mathrm{~N}-\mathrm{H})$, $2950,1580,1490,1330,1250$ (Ar-O-C), 1055, 1035, 1000, $740 \mathrm{~s} ;{ }^{1} \mathrm{H}$ NMR $\left(\mathrm{THF}-d_{8}\right) \delta: 9.30-7.54(\mathrm{~m}, 12 \mathrm{H}), 4.74-4.23$ $(\mathrm{m}, 8 \mathrm{H}), 1.64-1.19(\mathrm{~m}, 36 \mathrm{H}),-0.18(\mathrm{~m}, 2 \mathrm{H})$; EI-MS $\mathrm{m} / z(\%)$ : $858\left(\mathrm{M}^{+}, 100\right), 578(17), 205$ (30), 71 (18), 28 (29). Anal. calcd. for $\mathrm{C}_{52} \mathrm{H}_{58} \mathrm{~N}_{8} \mathrm{O}_{4}$ : C 72.73, H 6.76, $\mathrm{N} \mathrm{13.05;} \mathrm{found:} \mathrm{C}$ $72.56, \mathrm{H} 6.60, \mathrm{~N} 12.87$.

\section{General methods of bisphthalonitrile syntheses}

Method I (refs. 4, 33)

The distilled or recrystallized diol was placed in a $50 \mathrm{~mL}$ round-bottom flask equipped with a magnetic stirrer and distilled DMSO or DMF was added $(5 \mathrm{~mL} / \mathrm{mmol}$ diol $)$ and heated to $50^{\circ} \mathrm{C}$. Anhydrous $\mathrm{K}_{2} \mathrm{CO}_{3}$ (3-4 molar equiv.) and $2.2-2.5$ equivalents of 3 -nitrophthalonitrile $(1)(8,9)$ were added, the joint was well greased, fitted with a $\mathrm{MgSO}_{4}$ drying tube, and the slurry stirred at rt, producing a pink-red coloured heterogeneous mixture. Two additional 0.25 equivalents of $\mathrm{K}_{2} \mathrm{CO}_{3}$ were then added at $24 \mathrm{~h}$ intervals and the mixture stirred for an additional 3 days or until all of 1 had been consumed. At each $24 \mathrm{~h}$ interval, the reaction slurry was briefly homogenized by sonication and the component profile monitored by TLC $(10 \%$ $\mathrm{CH}_{3} \mathrm{CN}-\mathrm{Bz}$ ).

At the end of the reaction period the mixture was poured into ice-water, the flask rinsed with water, and the rinsings were added to the ice-water. The orange-brown precipitate was collected by centrifugation, washed with $40 \mathrm{~mL}$ of $10 \%$ $\mathrm{NaHCO}_{3}$ (aq.) (removing red-coloured products and yellowcoloured 3-hydroxyphthalonitrile (2)), and then with water. The residue was then washed with methanol, removing yellow coloured materials (mono-reacted diol and any excess 1 ). The crude off-white coloured product was analyzed by TLC and recrystallized from either hot ethyl acetate, methanol, acetone, benzene, or acetonitrile. If TLC analysis indicated the presence of impurities (in particular, BDPE ${ }^{2}$ ) in excess of approx- 
imately $15 \%$, the crude product was first purified by column chromatography using silica gel adsorbant and $10 \% \mathrm{CH}_{3} \mathrm{CN}-$ $\mathrm{Bz}$ as the eluting solvent and then recrystallized. The white bisphthalonitrile was dried overnight at $70^{\circ} \mathrm{C}$ at $10^{-3}$ Torr (1 Torr $=133.3 \mathrm{~Pa}$ ).

\section{Method II}

The distilled or recrystallized diol was placed in a $50 \mathrm{~mL}$ round-bottom flask equipped with a magnetic stirrer and distilled DMSO was added ( $5 \mathrm{~mL} / \mathrm{mmol}$ diol). Anhydrous $\mathrm{K}_{2} \mathrm{CO}_{3}$ ( 0.54 equiv.) and 0.50 equivalent of 1 were added; the joint was well greased and then fitted with a Quick-Fit stopcock valve. The flask was evacuated to an internal pressure of approximately 20 Torr, the valve closed, and the mixture stirred rapidly at $\mathrm{rt}$, immediately producing a pale pink heterogeneous mixture.

At $24 \mathrm{~h}$ intervals, the reaction slurry was briefly homogenized by brief sonication (with swirling) and the component profile monitored by TLC ( $\left.10 \% \mathrm{CH}_{3} \mathrm{CN}-\mathrm{Bz}\right)$. The flask was reevacuated and the slurry stirred. If all of 1 had been consumed, additional aliquots of carbonate ( 0.54 equiv.) and of 1 ( 0.50 equiv.) were added prior to evacuation and stirring. After the addition of $2.20-2.50$ equivalents of 1 , the mixture was stirred for an additional $24 \mathrm{~h}$ and then monitored by TLC. Additional $\mathrm{K}_{2} \mathrm{CO}_{3}$ (0.5-1.5 equiv.) was added if unreacted 1 was present and the mixture then stirred for a further $24-96 \mathrm{~h}$. The reaction mixture was then worked up as for Method I.

\section{2,2-Dipentylpropan-1,3-diol (8)}

In a manner similar to that previously described (19), a solution of $3.00 \mathrm{~g} \mathrm{(10.0} \mathrm{mmol)} \mathrm{of} \mathrm{diethyl} \mathrm{2,2-dipentylmalonate} \mathrm{(13)} \mathrm{in} 4$ $\mathrm{mL}$ of $\mathrm{Et}_{2} \mathrm{O}$ was added dropwise to a stirred $5-10^{\circ} \mathrm{C}$ suspension

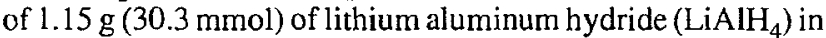
$25 \mathrm{~mL}$ of $\mathrm{Et}_{2} \mathrm{O}$. After addition of the diester, the mixture was heated at reflux for $2 \mathrm{~h}$ and then stirred at RT overnight. Active $\mathrm{LiAlH}_{4}$ was quenched by addition of $2 \mathrm{~mL}$ of EtOAc and then $2 \mathrm{~mL}$ of $95 \% \mathrm{EtOH}$. The inorganic salts were removed by filtration through Celite, washed with $\mathrm{Et}_{2} \mathrm{O}$, and the filtrate was concentrated to dryness under reduced pressure. The oily residue was dissolved in $30 \mathrm{~mL}$ of $\mathrm{Et}_{2} \mathrm{O}$ and extracted successively with $20 \mathrm{~mL}$ portions of $6 \mathrm{M} \mathrm{NaOH}, 4 \mathrm{M} \mathrm{HCl}$, twice with $40 \mathrm{~mL}$ of $\mathrm{H}_{2} \mathrm{O}$, and finally with one $10 \mathrm{~mL}$ portion of brine. The organic phase was dried over $\mathrm{MgSO}_{4}$ and then filtered. The filtrate was evaporated under reduced pressure to give $903 \mathrm{mg}$ of a pale yellow oil. Distillation of this oil under reduced pressure gave $800 \mathrm{mg} \mathrm{(37 \% )} \mathrm{of} \mathrm{diol} 8$ as a clear, colourless oil, bp 114 $117^{\circ} \mathrm{C} / 5 \times 10^{-3}$ Torr; ${ }^{1} \mathrm{H}$ NMR $\left(\mathrm{CDCl}_{3}\right): 3.92(\mathrm{~s}, 2 \mathrm{H}, \mathrm{OH})$, $3.52\left(\mathrm{~s}, 4 \mathrm{H}, \mathrm{CH}_{2} \mathrm{OH}\right), 1.37-1.24\left(\mathrm{~m}, 16 \mathrm{H}, 4 \times \mathrm{CH}_{2}\right), 0.90$ $\left(\mathrm{t}, 6 \mathrm{H}, J=7 \mathrm{~Hz}, \mathrm{CH}_{3}\right) ;{ }^{13} \mathrm{C}$ NMR $\left(\mathrm{CDCl}_{3}\right) \delta: 69.45,41.03$, $32.77,30.80,22.58,22.52,14.04$; CI-MS $\left(\mathrm{NH}_{3}\right) \mathrm{m} / \mathrm{z}(\%): 234$ $\left(\mathrm{M}^{+}+1+\mathrm{NH}_{3}, 100\right)$. Hygroscopic 8 was analyzed as its product 12.

\section{2,2-Dioctylpropan-1,3-diol (9)}

In a manner similar to the preparation of diol 8 , a solution of $7.75 \mathrm{~g}(20.0 \mathrm{mmol})$ of diethyl 2,2-dioctylmalonate (14) in 30 $\mathrm{mL}$ of $\mathrm{Et}_{2} \mathrm{O}$ was added dropwise to a stirred $5-10^{\circ} \mathrm{C}$ suspension of $3.00 \mathrm{~g}(80.0 \mathrm{mmol})$ of $\mathrm{LiAlH}_{4}$ in $50 \mathrm{~mL}$ of Et $\mathrm{t}_{2} \mathrm{O}$. After addition of the diester, the mixture was heated to reflux for $2 \mathrm{~h}$ and then stirred at RT overnight. Active $\mathrm{LiAlH}_{4}$ was quenched by addition of $5 \mathrm{~mL}$ of EtOAc and then $5 \mathrm{~mL}$ of $95 \% \mathrm{EtOH}$ (aq.). The inorganic salts were removed by filtration through Celite, washed with $\mathrm{Et}_{2} \mathrm{O}$, and the filtrate was concentrated to dryness under reduced pressure. The sticky white residue was dissolved in $60 \mathrm{~mL}$ of $\mathrm{Et}_{2} \mathrm{O}$ and extracted successively with 40 $\mathrm{mL}$ portions of $6 \mathrm{M} \mathrm{NaOH}, 4 \mathrm{M} \mathrm{HCl}$, twice with $40 \mathrm{~mL}$ of $\mathrm{H}_{2} \mathrm{O}$, and finally with one $10 \mathrm{~mL}$ portion of brine. The organic phase was dried over $\mathrm{MgSO}_{4}$ and evaporated under reduced pressure to give a yellowish oil. Distillation of the residue under reduced pressure gave $4.13 \mathrm{~g}(69 \%)$ of diol 9 as a colourless viscous oil that slowly solidified to a white wax at RT $\left(23^{\circ} \mathrm{C}\right)$, bp $159-162^{\circ} \mathrm{C} / 5 \times 10^{-3}$ Torr; IR $\left(\mathrm{cm}^{-1}\right): 3500$ $3200 \mathrm{br}(\mathrm{OH}), 2950,2860,1470,1380 \mathrm{w}, 1030,720 ;{ }^{1} \mathrm{H}$ NMR $\left(\mathrm{CDCl}_{3}\right)$ 8: $3.56(\mathrm{~s}, 4 \mathrm{H}), 1.27-1.22(\mathrm{br} \mathrm{m}, 30 \mathrm{H}), 0.88(\mathrm{t}, 6 \mathrm{H}$, $J=7 \mathrm{~Hz}) ;{ }^{13} \mathrm{C} \mathrm{NMR}\left(\mathrm{CDCl}_{3}\right) \delta: 69.47\left(\mathrm{CH}_{2} \mathrm{OH}\right), 41.00\left(4^{\circ} \mathrm{C}\right)$, $31.88,30.79,30.58,29.55,29.32,22.85,22.66,14.08$ $\left(\mathrm{CH}_{2} \mathrm{CH}_{3}\right)$; EI-MS m/z (\%): 282 (2), 269 (22), 252 (19), 154 (22), 139 (27), $111(33), 97(60), 83$ (79), 69 (100). Anal.

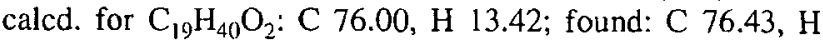
13.96.

\section{1,3-Bis $\left(2^{\prime}, 3^{\prime}\right.$-dicyanophenoxy)-2-methyl-2- trityloxymethylpropane (10)}

Bisphthalonitrile 10 was prepared by Method II from $0.900 \mathrm{~g}$ $(2.49 \mathrm{mmol})$ of diol $6(12), 1.159 \mathrm{~g}(6.70 \mathrm{mmol})$ of 3-nitrophthalonitrile (1), and $1.460 \mathrm{~g}(10.6 \mathrm{mmol})$ of $\mathrm{K}_{2} \mathrm{CO}_{3}$ in 20 $\mathrm{mL}$ of DMSO at RT over a 6 day period. Aqueous work-up and $\mathrm{EtOH}$ washing of the crude product gave a pink coloured crude product. Recrystallization of this crude product from EtOAc-hexanes gave $1.44 \mathrm{~g} \mathrm{(94 \% )}$ of white crystalline $\mathbf{1 0}$ (TLC: $10 \% \mathrm{CH}_{3} \mathrm{CN}-\mathrm{Bz}, R_{\mathrm{f}}=0.85$ ), $\mathrm{mp} 233-235^{\circ} \mathrm{C}$; IR $\left(\mathrm{cm}^{-1}\right): 3090,2920,2220(\mathrm{C} \equiv \mathrm{N}), 1580,1450,1290,1060$, 790,$700 ;{ }^{1} \mathrm{H} N M R\left(\mathrm{CD}_{3} \mathrm{CN}\right) \delta: 7.72(\mathrm{t}, 2 \mathrm{H}, J=8 \mathrm{~Hz}), 7.5-7.2$ $(\mathrm{m}, 19 \mathrm{H}), 4.22(\mathrm{~s}, 4 \mathrm{H}), 3.30(\mathrm{~s}, 2 \mathrm{H}), 1.27(\mathrm{~s}, 3 \mathrm{H}) ;{ }^{13} \mathrm{C}$ NMR (acetone- $d_{6}$ ) $\delta: 162.02,144.71,136.30,129.42,128.63$, $127.84,126.46,118.73,117.00,116.25,113.76,105.07$, 87.43, 72.02, 64.50, 41.83, 17.58; EI-MS m/z (\%): $614\left(\mathrm{M}^{+}\right.$, 6), 537 (9), 243 (100), 165 (35), 105 (29). Anal. calcd. for $\mathrm{C}_{40} \mathrm{H}_{30} \mathrm{~N}_{4} \mathrm{O}_{3}$ : C 78.19, H 4.88, N 9.12; found: C 77.66, H 4.75, $\mathrm{N} 9.30$

\section{1,3-Bis $\left(2^{\prime}, 3^{\prime}\right.$-dicyanophenoxy)-2,2-diethylpropane (11)} Bisphthalonitrile 11 was prepared by Method II from $692 \mathrm{mg}$ (5.23 mmol) of commercially available 2,2-diethylpropan1,3-diol (7), $2.00 \mathrm{~g}(11.56 \mathrm{mmol})$ of 1 , and $3.05 \mathrm{~g}(22.1 \mathrm{mmol})$ of $\mathrm{K}_{2} \mathrm{CO}_{3}$ in $10 \mathrm{~mL}$ of DMSO over a 7 day period. The yield of off-white solid 11, after purification by column chromatography using $10 \%$ acetonitrile-benzene as eluting solvent and recrystallization from acetonitrile, was $870 \mathrm{mg}$ (43\%) (TLC: $\left.10 \% \mathrm{CH}_{3} \mathrm{CN}-\mathrm{Bz}, R_{\mathrm{f}}=0.79\right), \mathrm{mp} 216-218^{\circ} \mathrm{C} ; \mathrm{IR}\left(\mathrm{cm}^{-1}\right): 3080$, $2960,2220(\mathrm{C} \equiv \mathrm{N}), 1580 \mathrm{~s}, 1470,1450,1290,1050(\mathrm{C}-\mathrm{O})$, $795 \mathrm{~s} ;{ }^{1} \mathrm{H}$ NMR $\left(\mathrm{CD}_{3} \mathrm{CN}\right) \delta: 7.67(\mathrm{t}, 2 \mathrm{H}, J=8 \mathrm{~Hz}), 7.35(\mathrm{~d}, 2 \mathrm{H}$, $J=8 \mathrm{~Hz}), 7.34(\mathrm{~d}, 2 \mathrm{H}, J=8 \mathrm{~Hz}), 4.11(\mathrm{~s}, 4 \mathrm{H}), 1.63(\mathrm{q}, 4 \mathrm{H}, J=$ $15,7.5 \mathrm{~Hz}), 0.94(\mathrm{t}, 6 \mathrm{H}, J=7.5 \mathrm{~Hz}) ;{ }^{13} \mathrm{C}$ NMR (acetone- $d_{6}$ ) $\delta$ : $162.25,136.34,126.46,119.03,116.96,116.23,113.94$, $104.99,71.98,42.14,23.69,7.42$; EI-MS m/z (\%): $384\left(\mathrm{M}^{+}\right.$, 3), 259 (4), 241 (50), 145 (38), 97 (80), 55 (100). Anal. calcd. for $\mathrm{C}_{23} \mathrm{H}_{20} \mathrm{O}_{2} \mathrm{~N}_{4}$ : C 71.88, H 5.21, N 14.58; found: C 72.24, $\mathrm{H}$ $4.78, \mathrm{~N} 14.99$.

1,3-Bis(2',3'-dicyanophenoxy)-2,2-dipentylpropane (12) Bisphthalonitrile 12 was prepared by Method II from $0.72 \mathrm{~g}$ 
(3.3 mmol) of 2,2-dipentylpropan- I,3-diol (8), $1.40 \mathrm{~g}(8.1$ $\mathrm{mmol})$ of 1 , and $2.1 \mathrm{~g}(15.2 \mathrm{mmol})$ of $\mathrm{K}_{2} \mathrm{CO}_{3}$ in $7 \mathrm{~mL}$ of DMSO at RT over a 9 day period. Aqueous work-up and methanol washing of the solid reaction products gave a yellowish crude solid. Recrystallization of the crude product from acetonitrile gave $0.81 \mathrm{~g}(52 \%)$ of white crystalline 12 (TLC: $10 \%$ $\left.\mathrm{CH}_{3} \mathrm{CN}-\mathrm{Bz}, R_{\mathrm{f}}=0.78\right), \mathrm{mp} 173-174^{\circ} \mathrm{C}$; IR $\left(\mathrm{cm}^{-1}\right): 3080$, 2960, $2210(\mathrm{C} \equiv \mathrm{N}), 1585,1475,1285,1055,795 .{ }^{\prime} \mathrm{H}$ NMR $\left(\mathrm{CD}_{3} \mathrm{CN}\right) \delta: 7.71(\mathrm{t}, 2 \mathrm{H}, J=8 \mathrm{~Hz}), 7.45(\mathrm{~m}, 4 \mathrm{H}), 4.13(\mathrm{~s}, 4 \mathrm{H})$, $1.54(\mathrm{~m}, 4 \mathrm{H}), 1.3(\mathrm{~m}, 12 \mathrm{H}), 0.86(\mathrm{t}, 6 \mathrm{H}, J=7 \mathrm{~Hz}) ;{ }^{13} \mathrm{C} \mathrm{NMR}$ (acetone- $d_{6}$ ) $\delta: 162.27,136.34,126.48,119.08,116.94$, $116.23,113.95,104.97,72.56,42.05,33.25,31.80,23.05$, 22.92, 14.22; El-MS $m / z(\%): 469\left(\mathrm{M}^{+}+1,50\right), 453(10), 439$ (18), 397 (21), 368 (30), 325 (72), 144 (100). Anal. calcd. for $\mathrm{C}_{29} \mathrm{H}_{32} \mathrm{~N}_{4} \mathrm{O}_{2}$ : C 74.36, $\mathrm{H}$ 6.84, N 11.97; found: C 74.20, H $6.93, \mathrm{~N} 12.00$.

\section{1,3-Bis(2',3'-dicyanophenoxy)-2,2-dioctylpropane (13)} Bisphthalonitrile 13 was prepared by Method II from $3.05 \mathrm{~g}$ (10.2 mmol) of 2,2-dioctylpropan-1,3-diol (9), $3.9 \mathrm{~g}(22.5$ mmol) of 1 , and $7.4 \mathrm{~g}(54 \mathrm{mmol})$ of $\mathrm{K}_{2} \mathrm{CO}_{3}$ in $25 \mathrm{~mL}$ of DMSO at RT over an 8 day period. Aqueous work-up and methanol washing of the solid reaction products gave a crude yellowish solid that was recrystallized from acetonitrile. A second recrystallization from ethyl acetate gave $3.17 \mathrm{~g} \mathrm{(57 \% )}$ of white crystalline 13 (TLC: $10 \% \mathrm{CH}_{3} \mathrm{CN}-\mathrm{Bz}, R_{\mathrm{f}}=0.80$ ), $\mathrm{mp} 163-$ $165^{\circ} \mathrm{C}$; FT-IR $\left(\mathrm{cm}^{-1}\right): 3083,2927,2862,2225\left(\mathrm{C}^{\prime} \mathrm{N}\right), 1518 \mathrm{~s}$, $1463,1294,1045,798 .{ }^{1} \mathrm{H}$ NMR (acetone- $\left.d_{6}\right) \delta: 7.86(\mathrm{t}, 2 \mathrm{H}, J$ $=8 \mathrm{~Hz}), 7.71(\mathrm{~d}, 2 \mathrm{H}, J=8 \mathrm{~Hz}), 7.55(\mathrm{~d}, 2 \mathrm{H}, J=8 \mathrm{~Hz}), 4.31(\mathrm{~s}$, $4 \mathrm{H}), 1.64(\mathrm{~m}, 4 \mathrm{H}), 1.32(\mathrm{~m}, 24 \mathrm{H}), 0.84(\mathrm{t}, 6 \mathrm{H}, J=7 \mathrm{~Hz}) ;{ }^{13} \mathrm{C}$ NMR (acetone- $d_{6}$ ) $\delta: 162.26,136.35,126.46,119.06,116.95$, $116.22,113.94,104.99,72.48,42.06,32.54,31.66,30.94$, $29.88,23.26,23.11,14.30 ;$ EI-MS $m / z(\%): 552\left(\mathrm{M}^{+}, 4.7\right), 523$ (4.6), 509 (2.8), 495 (2.4), 469 (3.4), 409 (55), 145 (22), 43 (100). Anal. calcd. for $\mathrm{C}_{35} \mathrm{H}_{44} \mathrm{~N}_{4} \mathrm{O}_{2}: \mathrm{C} 76.09, \mathrm{H} 7.97, \mathrm{~N} \mathrm{10.14}$; found: C 75.92, H 8.52, N 10.27 .

\section{General method of bis side-strapped phthalocyanine synthesis}

A solution of the bisphthalonitrile was made using 1-octanol, tetrahydrofuran (THF), or mixtures of 1-octanol and THF. A syringe pump was used to add the bisphthalonitrile dropwise (ca. $0.02 \mathrm{mmol} / \mathrm{min}$ ) to lithium octoxide in 1 -octanol heated at reflux (ca. $196^{\circ} \mathrm{C}$ ) in a modified air-cooled distillation apparatus that allowed rapid removal of cosolvent. In general, $10 \mathrm{~mL}$ of 1-octanol containing excess lithium metal was used for every $100 \mathrm{mg}$ of bisphthalonitrile added. Pc formation was usually evident after $20 \mathrm{~s}$ of bisphthalonitrile addition. Upon addition of the bisphthalonitrile, the mixture was heated at reflux for an additional 2-10 $\mathrm{min}$ and then allowed to cool to RT. Water was then added and the mixture neutralized by addition of $\mathrm{HCl}$ (aq.) (ca. $\mathrm{pH} 7$ ), giving a suspension that was homogenized by ultrasound. The mixture was then concentrated to near dryness under reduced pressure and the crude $\mathrm{Pc}$ product purified by centrifugation and chromatographic and recrystallization techniques.

\section{1,25:11,15-Bis ( $2^{\prime}$-methyl-2'-trityloxymethylpropan-1',3'- dioxy)phthalocyanine (14)}

$\mathrm{PcH}_{2} 14$ was prepared, using the general method, by an $18 \mathrm{~min}$ dropwise addition of a solution of $300 \mathrm{mg}(0.49 \mathrm{mmol})$ bis- phthalonitrile 6 in $7 \mathrm{~mL}$ of THF to $30 \mathrm{~mL}$ of 1 -octanol containing $50 \mathrm{mg}(2.2 \mathrm{mmol})$ of cleaned lithium metal at $200^{\circ} \mathrm{C}$. After addition of 6 , the mixture was heated at reflux for an additional $5 \mathrm{~min}$ and then cooled to RT. A general method work-up (similar to that of 17) gave $200 \mathrm{mg}$ of a blue-green crude solid. The solid was dissolved in THF, adsorbed on normal grade silica gel, then purified by flash chromatography (benzene as eluant) to yield a first fraction of almost pure 14 (determined by TLC). $\mathrm{PcH}_{2} 14$ was rechromatographed under the same conditions to yield $48 \mathrm{mg}(16 \%)$ of 14 as a dark blue solid, $\mathrm{mp}$ $>350^{\circ} \mathrm{C}$; IR $\left(\mathrm{cm}^{-1}\right): 3280(\mathrm{~N}-\mathrm{H}), 3050,2910,2860,1580$, 1480,1250 (Ar-O-C), 1030, 745, 700; UV-VIS (THF) $\lambda_{\max }$ $n m \log \varepsilon: 330$ (4.75), $618(4.45), 656$ (4.64), $680(5.11), 712$ (5.13); ${ }^{1} \mathrm{H}$ NMR (380 K)(pyridine- $\left.d_{5}\right) \delta: 9.07(\mathrm{~m}, 4 \mathrm{H}), 8.06$ $(\mathrm{m}, 16 \mathrm{H}), 7.84(\mathrm{~d}, 4 \mathrm{H}, J=6 \mathrm{~Hz}), 7.57(\mathrm{~m}, 14 \mathrm{H}), 7.40(\mathrm{t}, 4 \mathrm{H}, J$ $=7 \mathrm{~Hz}), 5.41(\mathrm{~m}, 4 \mathrm{H}), 5.21(\mathrm{~m}, 4 \mathrm{H}), 4.00$ and $3.99(2 \mathrm{~s}, 4 \mathrm{H})$, 1.93 and $1.92(2 \mathrm{~s}, 6 \mathrm{H}),-1.70$ (br s, 2H); +FAB-MS m/z: 1231 $\left(\mathrm{M}^{+}+1\right)$. Anal. calcd. for $\mathrm{C}_{80} \mathrm{H}_{62} \mathrm{~N}_{8} \mathrm{O}_{6}: \mathrm{C} 78.05, \mathrm{H} \mathrm{5.04,} \mathrm{N}$ 9.11; found: C 77.93, H 5.21, N 8.88.

\section{1,25:11,15-Bis $\left(2^{\prime}, 2^{\prime}\right.$-diethylpropan-1', $3^{\prime}$ - dioxy)phthalocyanine (15)}

Cleaned lithium metal $(50 \mathrm{mg}, 7.1 \mathrm{mmol})$ and 1-octanol $(50$ $\mathrm{mL}$ ) were placed in a $100 \mathrm{~mL}$ three-neck flask and the mixture heated to $195-200^{\circ} \mathrm{C}$ until lithium 1 -octoxide formation was complete. The flask was fitted for the modified distillation and a solution of $500 \mathrm{mg}(1.3 \mathrm{mmol})$ of bisphthalonitrile 11 in 30 $\mathrm{mL}$ of THF was prepared. A syringe pump was used to add the solution of 11 to the well-stirred alkoxide at $195-200^{\circ} \mathrm{C}$ over a $20 \mathrm{~min}$ period and the evaporated THF was collected. The mixture was then heated for an additional $5 \mathrm{~min}$ and then cooled to RT. Water ( $5 \mathrm{~mL}$ ) was added and the mixture was concentrated to near dryness under reduced pressure and then neutralized by the addition of dilute $\mathrm{HCl}$ (aq.). The solid material was suspended in $15 \mathrm{~mL}$ of $\mathrm{MeOH}$ and homogenized by ultrasound. The grey-green solid was collected and washed by repeated centrifugation and resuspension in $\mathrm{MeOH}$. Finally, the pellet was dissolved in $5 \mathrm{~mL}$ of $50 \% \mathrm{THF}-\mathrm{Bz}$ and purified by silica-gel flash chromatography using benzene as the eluting solvent. A first fraction consisting of a diffuse band of blue pigment was collected. Immobile green and brown materials were not eluted from the column. The solvent of the collected fraction (ca. $300 \mathrm{~mL}$ ) was removed under reduced pressure to yield $35 \mathrm{mg}(7 \%)$ of $\mathrm{PcH}_{2} 15$ as a blue solid, $\mathrm{mp}>350^{\circ} \mathrm{C}$; IR $\left(\mathrm{cm}^{-1}\right): 3280(\mathrm{~N}-\mathrm{H}), 2930,2840,1590,1450,1250$ (Ar-O-C), $1040,810,750 \mathrm{~s}$. UV-VIS (benzene) $\lambda_{\max } \mathrm{nm}(\log \epsilon): 352$ (4.75), 614 (4.52), $646(4.70), 672(5.11), 708$ (5.14). ' $\mathrm{H}$ NMR $\left(\mathrm{CF}_{3} \mathrm{COOD}\right) 8: 9.05(\mathrm{~d}, 4 \mathrm{H}, J=8 \mathrm{~Hz}), 8.49(\mathrm{t}, 4 \mathrm{H}, J=8 \mathrm{~Hz})$, $8.03(\mathrm{~d}, 4 \mathrm{H}, J=8 \mathrm{~Hz}), 5.10(\mathrm{~s}, 8 \mathrm{H}), 2.13(\mathrm{q}, 8 \mathrm{H}, J=7 \mathrm{~Hz}), 1.25$ (t, $12 \mathrm{H}, J=7 \mathrm{~Hz}$ ); EI-MS $m / z(\%): 770\left(\mathrm{M}^{+}, 35\right), 211(10), 145$ (31), 55 (100); HRMS required for $\mathrm{C}_{46} \mathrm{H}_{42} \mathrm{~N}_{8} \mathrm{O}_{4}: 770.33290$; found: 770.33220 .

\section{1,25:11,15-Bis $\left(2^{\prime}, 2^{\prime}\right.$-dipentylpropan-1',3' - dioxy)phthalocyanine (16)}

$\mathrm{PcH}_{2} 16$ was prepared as above from a $3 \mathrm{~mL}$ THF/1-octanol (2:1) solution of $150 \mathrm{mg}\left(3.21 \times 10^{-2} \mathrm{mmol}\right)$ of bisphthalonitrile 12 added over a $5 \mathrm{~min}$ period to $15 \mathrm{~mL}$ of 1 -octanol containing $15 \mathrm{mg}(2.2 \mathrm{mmol})$ of lithium metal at $195-200^{\circ} \mathrm{C}$. The mixture was heated for an additional $2 \mathrm{~min}$, cooled to $\mathrm{RT}$ and worked up as previously described. $\mathrm{PcH}_{2} 16$ was separated 
from dimeric and oligomeric Pc products by flash column chromatography ( $3 \% \mathrm{Bz}$-toluene as eluting solvent) as a fast moving blue pigment $\mathrm{F} 1$. A slower moving blue-green component was eluted after changing the eluting solvent to $1 \% \mathrm{THF}-$ toluene. The desired fast moving mononuclear Pc pigment 16 was then treated twice by flash column chromatography ( $3 \%$ $\mathrm{Bz}-$ toluene as eluting solvent). This pigment was recrystallized from pyridine to yield $31.5 \mathrm{mg}(21 \%)$ of $\mathrm{PcH}_{2} 16$ as a bright blue solid, $\mathrm{mp}>350^{\circ} \mathrm{C}$; IR $\left(\mathrm{cm}^{-1}\right): 3300(\mathrm{~N}-\mathrm{H}), 2940$, $2850,1585 \mathrm{w}, 1460,1250$ (Ar-O-C), 1035, 800w, 745s; UVVIS (THF) $\lambda_{\max } \mathrm{nm}(\log \epsilon): 352.5$ (4.76), 614 (4.53), 645 (4.70), $674(5.10), 709(5.14) ;{ }^{1} \mathrm{H}$ NMR (benzene- $\left.d_{6}\right) \delta: 8.87$ $(\mathrm{d}, 4 \mathrm{H}, J=8 \mathrm{~Hz}), 8.28(\mathrm{t}, 4 \mathrm{H}, J=8 \mathrm{~Hz}), 7.75(\mathrm{~d}, 4 \mathrm{H}, J=8 \mathrm{~Hz})$, $4.83(\mathrm{~s}, 8 \mathrm{H}), 1.90(\mathrm{~m}, 8 \mathrm{H}), 1.54(\mathrm{~m}, 8 h), 1.32(\mathrm{~m}, 16 \mathrm{H}), 0.80$ $(\mathrm{m}, 12 \mathrm{H}),-4.5(\mathrm{~s}, 2 \mathrm{H}) ;+\mathrm{FAB}-\mathrm{MS} \mathrm{m} / \mathrm{z}(\%): 940\left(\mathrm{M}^{+}, 2\right), 869$ (1.2), 772 (1), 759 (1), 687 (0.5), 614 (1.5), 460 (5), 307 (34), 154 (100). Anal. calcd. for $\mathrm{C}_{58} \mathrm{H}_{66} \mathrm{~N}_{8} \mathrm{O}_{4}: \mathrm{C} 76.05, \mathrm{H} 8.02, \mathrm{~N}$ 10.14; found: C 75.92, H 8.52, N 10.27.

\section{$1,25: 11,15-\mathrm{Bis}\left(2^{\prime}, 2^{\prime}\right.$-dioctylpropan-1', $3^{\prime}$ - dioxy)phthalocyanine (17)}

$\mathrm{PcH}_{2} 17$ was prepared as for 15 from a $20 \mathrm{~mL}$ THF/1-octanol (2:1) solution of $1.11 \mathrm{~g}(2.02 \mathrm{mmol})$ of bisphthalonitrile 13 added over a $7 \mathrm{~min}$ period to $75 \mathrm{~mL}$ of 1 -octanol containing 85 $\mathrm{mg}(12.1 \mathrm{mmol})$ of lithium metal at $195-200^{\circ} \mathrm{C}$. The mixture was heated for an additional $5 \mathrm{~min}$, cooled to RT and worked up as previously described. The desired $\mathrm{PcH}_{2} 17$ was separated from oligomeric Pc pigments by flash chromatography (benzene as eluting solvent). Flash chromatography of this nearly pure pigment (benzene as eluting solvent) gave $207 \mathrm{mg}$ (19\%) of 17 as a dark blue, shining solid, $\mathrm{mp}>350^{\circ} \mathrm{C}$; IR $\left(\mathrm{cm}^{-1}\right)$; $3290(\mathrm{~N}-\mathrm{H}), 2930,2850,1590 \mathrm{w}, 1460 \mathrm{w}, 1255$ (Ar-O-C), $1030,805 \mathrm{w}, 740 \mathrm{~s}$; UV-VIS (THF) $\lambda_{\max } \mathrm{nm}(\log \epsilon): 352.5$ (4.79), 613 (4.58), $646(4.73), 675(5.12), 709(5.17) ;{ }^{1} \mathrm{H}$ NMR (benzene- $\left.d_{6}\right) \delta: 7.92(\mathrm{~d}, 4 \mathrm{H}, J=7 \mathrm{~Hz}), 7.25(\mathrm{t}, 4 \mathrm{H}, J=7 \mathrm{~Hz})$, $6.88(\mathrm{~d}, 4 \mathrm{H}, J=7 \mathrm{~Hz}), 4.44(\mathrm{~s}, 8 \mathrm{H}), 1.58-1.88(\mathrm{~m}, 56 \mathrm{H}), 1.15$ (t, $12 \mathrm{H}, J=6.8 \mathrm{~Hz}),-5.99(\mathrm{~s}, 2 \mathrm{H})$ (see Table 3); EI-MS $\mathrm{m} / \mathrm{z}$ (\%): $1107\left(\mathrm{M}^{+}+1,32\right), 1077(5), 806(8), 660$ (18), $556(100)$. Anal. calcd. for $\mathrm{C}_{70} \mathrm{H}_{90} \mathrm{~N}_{8} \mathrm{O}_{4}$ : C 75.91, H 8.19, N 10.12; found: C 75.58, H 8.52, N 9.88.

\section{1,25:11,15-Bis (2'-methyl-2' -trityloxymethylpropan-1', $\mathbf{3}^{\prime}$ -} djoxy)phthalocyaninatozinc(II) (18)

PcZn 18 was prepared from $23 \mathrm{mg}\left(1.87 \times 10^{-2} \mathrm{mmol}\right)$ of $\mathrm{PcH}_{2}$ 14 and $50 \mathrm{mg}(0.27 \mathrm{mmol})$ of $\mathrm{Zn}(\mathrm{OAc})_{2}$ in a mixture of $2.5 \mathrm{~mL}$ of Py and $2.5 \mathrm{~mL}$ of DMF heated at reflux for $20 \mathrm{~h}$. After cooling to RT, the solvents were removed under reduced pressure and the crude product purified by column chromatography using $20 \%$ $\mathrm{THF}-\mathrm{Bz}$ as the eluting solvent. The solvents were removed under reduced pressure to give $22 \mathrm{mg}(91 \%)$ of PcZn 18, mp $>330^{\circ} \mathrm{C}$; UV-VIS (THF) $\lambda_{\max } \operatorname{nm}(\log \epsilon): 336$ (4.71), 617 (3.92), 654 (4.40), 686(5.33); ${ }^{1}$ HNMR (THF- $\left.d_{8}\right) 8: 9.02(\mathrm{~d}, 4 \mathrm{H}$, $J=7.5 \mathrm{~Hz}), 7.99(\mathrm{t}, 4 \mathrm{H}, J=7.5 \mathrm{~Hz}), 7.77(\mathrm{~m}, 12 \mathrm{H}), 7.68(\mathrm{~d}, 4 \mathrm{H}$, $J=7.5 \mathrm{~Hz}), 7.38(\mathrm{~m}, 12 \mathrm{H}), 7.26(\mathrm{~m}, 6 \mathrm{H}), 5.38(\mathrm{~m}, 4 \mathrm{H}), 5.17(\mathrm{~m}$, $4 \mathrm{H}), 3.66$ and $3.64(2 \mathrm{~s}, 4 \mathrm{H}), 1.65$ and $1.62(2 \mathrm{~s}, 6 \mathrm{H}) ;+\mathrm{FAB}-\mathrm{MS}$ $m / z$ : cluster at $1295(\mathrm{M}+2)$. Anal. calcd. for $\mathrm{C}_{80} \mathrm{H}_{60} \mathrm{~N}_{8} \mathrm{O}_{6} \mathrm{Zn}: \mathrm{C}$ 74.24, H4.64, N8.66; found: C 74.39, H 4.46, N 8.23.

\section{1,25:11,15-Bis $\left(2^{\prime}, 2^{\prime}\right.$-dipentylpropan- $1^{\prime}, 3^{\prime}$ -}

dioxy)phthalocyaninato zine(II) (19)

$\mathrm{PcH}_{2} 16\left(50 \mathrm{mg}, 5.3 \times 10^{-2} \mathrm{mmol}\right)$ was dissolved in a mixture of $10 \mathrm{~mL}$ of pyridine and $8 \mathrm{~mL}$ of DMF. Zinc acetate $(0.5 \mathrm{mg}$, $2.72 \mathrm{mmol}$ ) was added and the mixture heated to reflux for $14 \mathrm{~h}$. The mixture was allowed to cool, the solvents were removed under reduced pressure, and the crude product was purified by flash chromatography using THF as eluting solvent. The THF was removed under reduced pressure and the product recrystallized from pyridine to give $47 \mathrm{mg}(89 \%)$ of PcZn 19 as fine light-blue needles, $m p>350^{\circ} \mathrm{C}$; UV-VIS (THF) $\lambda_{\max } \mathrm{nm}(\log \epsilon): 356(4.74), 617$ (4.62), 655 (4.56), 686 (5.42); ${ }^{1} \mathrm{H}$ NMR (benzene- $\left.d_{6}\right) \delta: 8.87(\mathrm{~d}, 4 \mathrm{H}, J=8 \mathrm{~Hz}), 8.28(\mathrm{t}$, $4 \mathrm{H}, J=8 \mathrm{~Hz}), 7.74(\mathrm{~d}, 4 \mathrm{H}, J=8 \mathrm{~Hz}), 4.83(\mathrm{~s}, 8 \mathrm{H}), 1.91(\mathrm{~m}$, $8 \mathrm{H}), 1.54(\mathrm{~m}, 8 \mathrm{H}), 1.27(\mathrm{~m}, 16 \mathrm{H}), 0.80(\mathrm{t}, 12 \mathrm{H}, J=6.7)$; +FAB-MS $m / z(\%): 1002\left(\mathrm{M}^{+}+1,100\right), 932(10), 821(18)$, 640 (29), 634 (27), 610 (23). Anal. calcd. for $\mathrm{C}_{58} \mathrm{H}_{64} \mathrm{~N}_{8} \mathrm{O}_{4} \mathrm{Zn}$ : C 69.48, H 6.43, N 11.18; found: C 69.51, H 6.50, N 10.92 .

\section{1,25:11,15-Bis $\left(2^{\prime}, 2^{\prime}\right.$-dioctylpropan-1', $3^{\prime}$ - dioxy)phthalocyaninato zinc(II) (20)}

$\mathrm{PcH}_{2} 17\left(67.7 \mathrm{mg}, 6.12 \times 10^{-2} \mathrm{mmol}\right)$ was added to a mixture of $20 \mathrm{~mL}$ of pyridine and $20 \mathrm{~mL}$ of DMF containing $112 \mathrm{mg}$ $(0.61 \mathrm{mmol})$ of $\mathrm{Zn}(\mathrm{OAc})_{2}$. The mixture was heated at reflux overnight and then cooled to RT. The solvents were removed under reduced pressure and the pigment purified by column chromatography ( $\mathrm{Et}_{2} \mathrm{O}$ as the eluting solvent). After evaporation of the solvent under reduced pressure, $62 \mathrm{mg}(87 \%)$ of PcZn 20 was obtained, $m p>330^{\circ} \mathrm{C}$; UV-VIS (THF) $\lambda_{\max } \mathrm{nm}$ (log $\epsilon$ ): 356 (4.63), 480 (3.11), 617 (4.49), 655 (4.46), 685.5 (5.17); ${ }^{1} \mathrm{H}$ NMR $\left(\mathrm{THF}-d_{8}\right) \delta: 8.94(\mathrm{~d}, 4 \mathrm{H}, J=7 \mathrm{~Hz}), 7.96(\mathrm{t}$, $4 \mathrm{H}, J=7 \mathrm{~Hz}), 7.56(\mathrm{~d}, 4 \mathrm{H}, J=7 \mathrm{~Hz}), 5.16(\mathrm{br} \mathrm{s}, 8 \mathrm{H}), 1.96(\mathrm{~m}$, $8 \mathrm{H}), 1.89(\mathrm{~m}, 8 \mathrm{H}), 1.60(\mathrm{~m}, 40 \mathrm{H}), 1.00(\mathrm{t}, 12 \mathrm{H}, J=7 \mathrm{~Hz})$; +FAB-MS $m / z(\%): 1171\left(\mathrm{M}^{+}+1,100\right), 905(34), 791$ (36), 641 (85), 626 (23), 612 (66). Anal. calcd. for $\mathrm{C}_{70} \mathrm{H}_{88} \mathrm{~N}_{8} \mathrm{O}_{4} \mathrm{Zn}$ : C 71.81, H 7.58, N 9.57; found: C 71.53, H 7.11, N 9.93.

\section{5,5-Bis( $2^{\prime}, 3^{\prime}$-dicyanophenoxymethyl)-2-phenyl-1,3- dioxane (23)}

Bisphthalonitrile 23 was prepared by Method II from $1.11 \mathrm{~g} \mathrm{(5}$ mmol) of 5,5-dihydroxymethyl-2-phenyl-1,3-dioxane (21) (19), $1.75 \mathrm{~g}$ (10.1 mmol) of 1 , and $3.1 \mathrm{~g}(22.5 \mathrm{mmol})$ of $\mathrm{K}_{2} \mathrm{CO}_{3}$ in $25 \mathrm{~mL}$ of DMSO at RT over a 16 day period. Aqueous work-up and methanol washing of the reaction products gave a pink-coloured solid. Double recrystallization of the pink solid from EtOAc gave $1.83 \mathrm{~g}(77 \%)$ of white crystalline 23 (TLC: $5 \% \mathrm{CH}_{3} \mathrm{CN}-\mathrm{Bz}, R_{\mathrm{f}}=0.43$ ), $\mathrm{mp} 180-182.5^{\circ} \mathrm{C}$; IR $\left(\mathrm{cm}^{-1}\right): 3180,3100 \mathrm{~s}, 2990,2880,2245(\mathrm{C} \equiv \mathrm{N}), 1585 \mathrm{~s}$, $1470 \mathrm{br}, 1395,1300 \mathrm{br}, 1115,1060 \mathrm{br}, 800 \mathrm{~s}, 740,700 \mathrm{~s} ;{ }^{1} \mathrm{H}$ $\operatorname{NMR}\left(\mathrm{CD}_{3} \mathrm{CN}\right) \delta: 7.74(\mathrm{t}, 2 \mathrm{H}, J=8 \mathrm{~Hz}), 7.60(\mathrm{~d}, 2 \mathrm{H}, J=8$ $\mathrm{Hz}), 7.50-7.36(\mathrm{~m}, 7 \mathrm{H}), 5.59(\mathrm{~s}, 1 \mathrm{H}), 4.70(\mathrm{~s}, 2 \mathrm{H}), 4.55(\mathrm{~d}, 2 \mathrm{H}$, $J=12 \mathrm{~Hz}), 4.19(\mathrm{~s}, 2 \mathrm{H}), 4.12(\mathrm{~d}, 2 \mathrm{H}, J=12 \mathrm{~Hz}) ;{ }^{13} \mathrm{C} \mathrm{NMR}$ $\left(\mathrm{DMSO}-d_{6}\right) \delta$ : 160.74 and $160.53,137.95,136.09$ and 136.02 , $129.07,128.19,126.31,126.20,118.94$ and $118.69,115.73$ and $115.70,115.29$ and $115.27,113.48$ and $113.39,103.45$ and $113.38,101.40,68.85,68.42,67.82,38.36 ;$ EI-MS $\mathrm{m} / \mathrm{z}$ (\%): $476\left(\mathrm{M}^{+}, 63\right), 475(23), 399(5), 197(60), 157(25), 105$ (100), 77 (22). Anal. calcd. for $\mathrm{C}_{28} \mathrm{H}_{20} \mathrm{~N}_{4} \mathrm{O}_{4}: \mathrm{C} 70.58, \mathrm{H} 4.23$, N 11.76; found: C 70.25, H 4.66, N 12.00 .

\section{1,1-Bis $\left(2^{\prime}, 3^{\prime}\right.$-dicyanophenoxymethyl)cyclohexane (24)} Bisphthalonitrile 24 was prepared by Method II from $0.72 \mathrm{~g}$ ( 5 mmol) of 1,1-dihydroxymethylcyclohexane (22) (20), $2.25 \mathrm{~g}$ (13 mmol) of 1 , and $2.65 \mathrm{~g}(19 \mathrm{mmol})$ of $\mathrm{K}_{2} \mathrm{CO}_{3}$ in $20 \mathrm{~mL}$ of 
DMSO over a 12 day period at RT. Aqueous work-up and methanol washing gave a pink coloured crude product. Double recrystallization of the crude product from acetone gave $1.28 \mathrm{~g}$ (65\%) of bisphthalonitrile 24 as colourless crystals (TLC: $10 \%$ $\left.\mathrm{CH}_{3} \mathrm{CN}-\mathrm{Bz}, \mathrm{R}_{\mathrm{f}}=0.63\right)$, mp $246-247^{\circ} \mathrm{C}$; IR $\left(\mathrm{cm}^{-1}\right): 3080 \mathrm{~s}$, $2910,2850,2220(\mathrm{C} \equiv \mathrm{N}), 1775 \mathrm{~s}, 1450 \mathrm{br}, 1290 \mathrm{br}, 1050,930$, 790s, 730; ${ }^{1} \mathrm{H} \mathrm{NMR}\left(\mathrm{CD}_{3} \mathrm{CN}\right) 8: 7.72(\mathrm{t}, 2 \mathrm{H}, J=8 \mathrm{~Hz}), 7.48(\mathrm{~d}$, $2 \mathrm{H}, J=8 \mathrm{~Hz}$ ), $7.42(\mathrm{~d}, 2 \mathrm{H}, J=8 \mathrm{~Hz}), 4.22(\mathrm{~s}, 4 \mathrm{H}), 1.69-1.53$ $(\mathrm{m}, 10 \mathrm{H}) ;{ }^{13} \mathrm{C}$ NMR (DMSO- $\left.d_{6}\right)(330 \mathrm{~K}) \delta: 160.84,135.40$, $125.21,118.60,115.17,114.94,112.90,103.06,72.24,38.02$, 28.87, 25.16, 20.32; EI-MS $m / z(\%): 396\left(\mathrm{M}^{+}, 32\right), 252(100)$, 157 (77), 144 (87), 127 (93). Anal. calcd. for $\mathrm{C}_{24} \mathrm{H}_{20} \mathrm{~N}_{4} \mathrm{O}_{2}: \mathrm{C}$ 72.73, H 5.05, N 14.14; found: C 73.03, H 4.77, N 13.78 .

\section{1,5-Bis $\left(2^{\prime}, 3^{\prime}\right.$-dicyanophenoxy)-3-oxapentane (31)}

Bisphthalonitrile 31 was prepared by Method II from $0.795 \mathrm{~g}$ $(7.50 \mathrm{mmol})$ of diethylene glycol $(25), 2.17 \mathrm{~g}(18.3 \mathrm{mmol})$ of 1 , and $3.04 \mathrm{~g}(22.1 \mathrm{mmol})$ of $\mathrm{K}_{2} \mathrm{CO}_{3}$ in $10 \mathrm{~mL}$ of DMSO at $50^{\circ} \mathrm{C}$ over a 6 day period. After work-up by Method I, bisphthalonitrile 31 was obtained from the crude product by column chromatography ( $15 \% \mathrm{CH}_{3} \mathrm{CN}-\mathrm{Bz}$ as the eluting solvent) as the first fraction collected. After recrystallization from acetonitrile, $509 \mathrm{mg}$ (19\%) of $\mathbf{3 1}$ was obtained as white needles (TLC: $15 \% \quad \mathrm{CH}_{3} \mathrm{CN}-\mathrm{Bz}, R_{\mathrm{f}}=0.50$ ), mp $223-224^{\circ} \mathrm{C}$; IR $\left(\mathrm{cm}^{-1}\right): 3090,2925,2220(\mathrm{C} \equiv \mathrm{N}), 1580,1470,1300,1140$, 1065, 795; ${ }^{1} \mathrm{H}$ NMR $\left(\mathrm{CD}_{3} \mathrm{CN}\right)$ 8: $7.70(\mathrm{t}, 2 \mathrm{H}, J=8 \mathrm{~Hz}), 7.45$ $(\mathrm{d}, 2 \mathrm{H}, J=8 \mathrm{~Hz}), 7.44(\mathrm{~d}, 2 \mathrm{H}, J=8 \mathrm{~Hz}), 4.34(\mathrm{t}, 4 \mathrm{H}, J=4 \mathrm{~Hz})$, $3.94(\mathrm{t}, 4 \mathrm{H}, J=4 \mathrm{~Hz}) ;{ }^{13} \mathrm{C}$ NMR (DMSO-d $\left.d_{6}\right)(330 \mathrm{~K}) \delta$ : $160.73,135.21,125.49,118.64,115.25,115.14,113.03$, 69.35, 68.57; EI-MS m/z (\%): $358\left(\mathrm{M}^{+}, 4.5\right), 215(17), 171$ (100), 145 (25), 116 (14). Anal. calcd. for $\mathrm{C}_{20} \mathrm{H}_{14} \mathrm{~N}_{4} \mathrm{O}_{3}: \mathrm{C}$ 67.04, H 3.91, N 15.64; found: C 66.73, H 3.87, N 15.42 .

A second fraction eluted from the column consisted of a mixture (by TLC) of $\mathrm{BDPE}^{2}$ and a monosubstitution product (etherol).

\section{1,2-Bis $\left(2^{\prime}, 3^{\prime}\right.$-dicyanophenoxymethyl)benzene (32)}

Bisphthalonitrile 32 was prepared by Method II from $1.068 \mathrm{~g}$ (7.5 mmol) of 1,2-dihydroxymethylbenzene (26) (Aldrich), $3.0 \mathrm{~g}(17.3 \mathrm{mmol})$ of 1 , and $3.0 \mathrm{~g}(2.1 .7 \mathrm{mmol})$ of $\mathrm{K}_{2} \mathrm{CO}_{3}$ in 10 $\mathrm{mL}$ of DMSO at RT over a 6 day period. After aqueous workup and washing with $\mathrm{MeOH}$ an off-white crude product was recovered. Recrystallization of the crude product from acetonitrile gave $760 \mathrm{mg}(26 \%)$ of white 32 as an amorphous solid (TLC: $5 \% \mathrm{CH}_{3} \mathrm{CN}-\mathrm{Bz}, R_{\mathrm{f}}=0.24$ ), mp $254-256^{\circ} \mathrm{C}$; FT-IR $\left(\mathrm{cm}^{-1}\right): 3167,3085,2924,2235(\mathrm{C} \equiv \mathrm{N}), 1583 \mathrm{~s}, 1469,1453$, $1272,1037,802,767,734 ;{ }^{1} \mathrm{H}$ NMR $\left(\mathrm{CDCl}_{3}\right) \delta: 7.83(\mathrm{t}, 2 \mathrm{H}$, $J=8 \mathrm{~Hz}), 7.73(\mathrm{~d}, 2 \mathrm{H}, J=8 \mathrm{~Hz}), 7.61(\mathrm{~m}, 4 \mathrm{H}), 7.46(\mathrm{~m}, 2 \mathrm{H})$, $5.54(\mathrm{~s}, 4 \mathrm{H}) ;{ }^{13} \mathrm{C} \mathrm{NMR}\left(\mathrm{CDCl}_{3}\right)$ 8: 169.24, 135.28, 133.34, $128.66,128.52,125.69,118.64,115.24,115.20,113.09$, 103.24, 68.88; EI-MS m/z (\%): ion signals not observed. Anal.

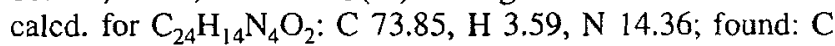
73.64, H 3.57, N 14.45.

\section{$2,2^{\prime}$-Bis $\left(2^{\prime \prime}, 3^{\prime \prime}\right.$-dicyanophenoxymethyl)biphenyl (33)}

Bisphthalonitrile 33 was prepared by Method II from $400 \mathrm{mg}$ (1.9 mmol) of 2,2'-dihydroxymethylbiphenyl (27) (21), 750 $\mathrm{mg}(4.34 \mathrm{mmol})$ of 1 , and $900 \mathrm{mg}(6.52 \mathrm{mmol})$ of $\mathrm{K}_{2} \mathrm{CO}_{3}$ in 10 $\mathrm{mL}$ of DMSO over 4 days at RT. After aqueous work-up and methanol washing, the yellowish crude product was recrystallized twice from benzene to give $370 \mathrm{mg}$ (42\%) of bisphtha- lonitrile 33 as an off-white solid (TLC: $15 \% \mathrm{CH}_{3} \mathrm{CN}-\mathrm{Bz}, R_{\mathrm{f}}=$

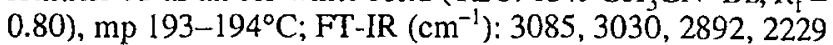
$(\mathrm{C} \equiv \mathrm{N}), 1581 \mathrm{~s}, 1470 \mathrm{~s}, 1301,1286,1034,801,789,692 ;{ }^{l} \mathrm{H}$ NMR $\left(\mathrm{CDCl}_{3}\right) \delta: 7.57(\mathrm{~m}, 4 \mathrm{H}), 7.42(\mathrm{~m}, 4 \mathrm{H}), 7.36(\mathrm{~m}, 2 \mathrm{H})$, $7.31(\mathrm{~d}, 2 \mathrm{H}, J=8 \mathrm{~Hz}), 7.17(\mathrm{~d}, 2 \mathrm{H}, J=8 \mathrm{~Hz}), 4.92(\mathrm{~m}, 4 \mathrm{H})$; ${ }^{13} \mathrm{C} \mathrm{NMR}\left(\mathrm{CDCl}_{3}\right)$ 8: 160.77, 139.94, 134.83, 132.19, 130.21, $130.04,129.06,128.54,125.22,116.98,116.88,115.19$, 113.14, 104.44, 70.04; EI-MS m/z (\%): $466\left(\mathrm{M}^{+}, 8\right), 463(10)$, 437 (9), 324 (42), 283 (38), 179 (100). Anal. calcd. for $\mathrm{C}_{30} \mathrm{H}_{18} \mathrm{~N}_{4} \mathrm{O}_{2}$ : C 77.25, H 3.86, N 12.02; found: $\mathrm{C} 76.85, \mathrm{H}$ $3.78, \mathrm{~N} 11.88$.

\section{1,3-Bis ( $2^{\prime}, 3^{\prime}$-dicyanophenoxymethyl $)$-5-tert-butylbenzene} (34)

Bisphthalonitrile 34 was prepared by Method II from $388 \mathrm{mg}$ (2.00 mmol) of 3,5-dihydroxymethyl-tert-butylbenzene (28) (22), $850 \mathrm{mg}(4.91 \mathrm{mmol})$ of 1 , and $1.06 \mathrm{~g}(7.68 \mathrm{mmol})$ of $\mathrm{K}_{2} \mathrm{CO}_{3}$ in $10 \mathrm{~mL}$ of $\mathrm{DMSO}$ at RT over a 5 day period. Aqueous work-up and methanol washing gave a greyish crude product. Recrystallization of this solid from acetonitrile gave $413 \mathrm{mg}$ (46\%) of white crystalline 34 (TLC: $15 \% \mathrm{CH}_{3} \mathrm{CN}-\mathrm{Bz}$, $\left.R_{\mathrm{f}}=0.76\right)$, mp 180-181 ${ }^{\circ} \mathrm{C}$; FT-IR $\left(\mathrm{cm}^{-1}\right): 3089,2954,2869$, $2234(\mathrm{C} \equiv \mathrm{N}), 1583 \mathrm{~s}, 1471,1295 \mathrm{~s}, 1083,795$; ' $\mathrm{H}$ NMR (acetone- $\left.d_{6}\right) \delta: 7.86(\mathrm{t}, 2 \mathrm{H}, J=8 \mathrm{~Hz}), 7.73(\mathrm{~d}, 2 \mathrm{H}, J=8 \mathrm{~Hz}), 7.67$ $(\mathrm{s}, 2 \mathrm{H}), 7.59(\mathrm{~d}, 2 \mathrm{H}, J=8 \mathrm{~Hz}), 7.48(\mathrm{~s}, 1 \mathrm{H}), 5.47(\mathrm{~s}, 4 \mathrm{H}), 1.36$ $(\mathrm{s}, 9 \mathrm{H}) ;{ }^{13} \mathrm{C}$ NMR (acetone- $\left.d_{6}\right) \delta: 162.03,153.12,136.72$, $136.16,126.61,125.63,124.77,119.42,117.30,116.32$, 114.05, 105.43, 72.23, 35.46, 31.54; EI-MS $m / z(\%): 446\left(\mathrm{M}^{+}\right.$, 15), 304 (46), 288 (38), 273 (12), 247 (100). Anal. calcd. for

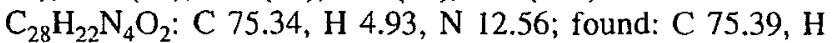
$4.96, \mathrm{~N} 12.55$.

\section{2,5-Bis (2', $3^{\prime}$-dicyanophenoxymethyl)furan (35)}

Bisphthalonitrile 35 was prepared by a modification of Method II (using less than 2 equiv. of 1) from $1.28 \mathrm{~g}$ (10.0 mmol) of 2,5-dihydroxymethylfuran 29 (Aldrich), $3.15 \mathrm{~g}$ (18.2 mmol) of 1 and $3.4 \mathrm{~g}(24.6 \mathrm{mmol})$ of $\mathrm{K}_{2} \mathrm{CO}_{3}$ in $25 \mathrm{~mL}$ of DMSO over a 6 day reaction period at RT. Aqueous work-up and $\mathrm{MeOH}$ washing of the reaction product gave a brown solid. Recrystallization of the highly insoluble crude product from $140 \mathrm{~mL}$ of acetone gave $1.94 \mathrm{~g}(56 \%, 1)$ of white crystalline 35 (TLC: $15 \% \mathrm{CH}_{3} \mathrm{CN}-\mathrm{Bz}, R_{\mathrm{f}}=0.57$ ), $\mathrm{mp}>330^{\circ} \mathrm{C}$; FT-IR $\left(\mathrm{cm}^{-1}\right): 3370,3090,2920,2232(\mathrm{C} \equiv \mathrm{N}), 1585 \mathrm{~s}, 1474 \mathrm{~s}$, $1275 \mathrm{~s}, 1030 \mathrm{~s}, 809 ;{ }^{1} \mathrm{H}$ NMR $\left(\mathrm{CD}_{3} \mathrm{CN}\right) \delta: 7.78(\mathrm{t}, 2 \mathrm{H}, J=8$ $\mathrm{Hz}), 7.60(\mathrm{~d}, 2 \mathrm{H}, J=8 \mathrm{~Hz}), 7.52(\mathrm{~d}, 2 \mathrm{H}, J=8 \mathrm{~Hz}), 6.66(\mathrm{~s}, 2 \mathrm{H})$, $5.29(\mathrm{~s}, 4 \mathrm{H}) ;{ }^{13} \mathrm{C}$ NMR (DMSO- $\left.d_{6}\right)(330 \mathrm{~K}) \delta: 159.92,149.45$, $135.17,125.94,118.96,115.35,115.20,112.94,112.11$, 103.44, 63.33; EI-MS m/z (\%): $382\left(\mathrm{M}^{+}+2,1.1\right), 237(85)$, 144 (75), 116 (100), 94 (97). Anal. calcd. for $\mathrm{C}_{22} \mathrm{H}_{12} \mathrm{~N}_{4} \mathrm{O}_{3}: \mathrm{C}$ 69.47, H 3.16, N 14.74; found: C 69.21, H 3.03, N 14.53.

\section{cis-2,5-Bis $\left(2^{\prime}, 3^{\prime}\right.$-dicyanophenoxymethyl)tetrahydrofuran}

Bisphthalonitrile 36 was prepared by Method II from $0.66 \mathrm{~g}$ ( 5 mmol) of cis-2,5-bis(hydroxymethyl)tetrahydrofuran (30) (23), $2.10 \mathrm{~g}(12.1 \mathrm{mmol})$ of 1 , and $2.40 \mathrm{~g}(17.4 \mathrm{mmol})$ of $\mathrm{K}_{2} \mathrm{CO}_{3}$ in $10 \mathrm{~mL}$ of DMSO at RT over a 10 day period. Workup and recrystallization from methanol gave $820 \mathrm{mg}(43 \%)$ of greyish-yellow crystalline 36 (TLC: $15 \% \mathrm{CH}_{3} \mathrm{CN}-\mathrm{Bz}, \mathrm{R}_{\mathrm{f}}=$ $0.55), \mathrm{mp} 186-188^{\circ} \mathrm{C}$; FT-IR $\left(\mathrm{cm}^{-1}\right): 3085,2977,2879,2226$ $(\mathrm{C} \equiv \mathrm{N}), 1563 \mathrm{~s}, 1465 \mathrm{~s}, 1260,1100,789 ;{ }^{1} \mathrm{H}$ NMR (acetone- $d_{6}$ ) 
$\delta: 7.81(\mathrm{t}, 2 \mathrm{H}, J=8 \mathrm{~Hz}), 7.62(\mathrm{~d}, 2 \mathrm{H}, J=8 \mathrm{~Hz}), 7.53(\mathrm{~d}, 2 \mathrm{H}$, $J=8 \mathrm{~Hz}), 4.39(\mathrm{~m}, 2 \mathrm{H}), 4.34(\mathrm{~m}, 2 \mathrm{H}, J=4.2 \mathrm{~Hz}), 4.29(\mathrm{~m}, 2 \mathrm{H}$, $J=4.2 \mathrm{~Hz}), 2.15(\mathrm{~m}, 4 \mathrm{H}) ;{ }^{13} \mathrm{C}$ NMR (acetone- $\left.d_{6}\right) \delta: 162.44$, $135.12,126.36,119.09,117.11,116.31,114.20,104.90$, 78.69, 72.72, 28.30; +FAB-MS m/z (\%): $385\left(\mathrm{M}^{+}+1,100\right)$. Anal. calcd. for $\mathrm{C}_{22} \mathrm{H}_{16} \mathrm{~N}_{4} \mathrm{O}_{3}: \mathrm{C} 68.75, \mathrm{H} 4.17, \mathrm{~N} 14.58$; found: $\mathrm{C} 68.65, \mathrm{H} 4.16, \mathrm{~N} 14.24$.

\section{Acknowledgement}

We are grateful to the Natural Sciences and Engineering Research Council of Canada for financial support of this research.

\section{References}

1. C.C. Leznoff. In Phthalocyanines; properties and applications. Vol. 1. Edited by C.C. Leznoff and A.B.P. Lever. VCH, New York. 1989.

2. S. Greenberg, A.B.P. Lever, and C.C. Leznoff. Can. J. Chem. 66, 1059 (1988).

3. S. Gaspard and Ph. Maillard. Tetrahedron, 43, 1083 (1987).

4. C.C. Leznoff, M. Hu, C.R. McArthur, Y. Qin, and J.E. van Lier. Can. J. Chem. 72, 1990 (1994).

5. M. Hanack, G. Renz, J. Strähle, and S. Schmid. J. Org. Chem. 66, 3501 (1991).

6. D.M. Drew and C.C. Leznoff. Synlett, 623 (1994).

7. M. Hanack, G. Schmid, and M. Sommerauer. Angew Chem. Int. Ed. Engl. 32, 1422 (1993).

8. V.M. Derkacheva, S.S. Iodko, O.L. Kaliya, and E.A. Luk'yanets. Zh. Obshch. Khim. 51, 2319 (1981).

9. C.C. Leznoff, D.S. Terekhov, C.R. McArthur, S. Vigh, and J. Li. Can. J. Chem. 73, 435 (1995); R.D. George and A.W. Snow. J. Heterocycl. Chem. 32, 495 (1995); D.M. Drew. Ph.D. Thesis, York University, 1995. pp. 50-52.

10. V.A. Ustinov, V.V. Plakhtinskii, G.X. Mironov, and N.S. Ryabukhina. Zh. Org. Khim. 15, 1775 (1979).

11. P.J. Brach, S.J. Grammatica, O.A. Ossanna, and L. Weinberger J. Heterocycl. Chem. 7, 1403 (1970); G. Pawlowski and M. Hanack. Synthesis, 287 (1980).
12. C.C. Leznoff, S.M. Marcuccio, S. Greenberg, A.B.P. Lever, and K.B. Tomer. Can. J. Chem. 63, 623 (1985).

13. A.W. Dox and E.G. Jones. J. Am. Chem. Soc. 50, 2033 (1928).

14. W.M. Stanley. M.S. Jay, and R. Adams. J. Am. Chem. Soc. 51 , 1261 (1929).

15. J.F.W. McOmie and W.L. Watts. Chem. Ind. 1658 (1963).

16. J.F.W. McOmie, M.L. Watts, and D.E. West. Tetrahedron, 24, 2289 (1968).

17. I. Rosenthal, E. Ben-Hur, S. Greenberg. A. Concepcion-Lam, D.M. Drew, and C.C. Leznoff. Photochem. Photobiol. 46, 959 (1987).

18. M.V . Bhatt and J.R. Babu. Tetrahedron Lett. 25, 3497 (1984); S. Anderson. Synthesis, 3497 (1984).

19. L.F. Fieser and M. Fieser. Reagents for organic synthesis. Vol. 1. J. Wiley and Sons, Inc., New York. 1967. p. 581.

20. G. Hummel and K. Ruhl. German Pat. 922,648 (1955); Chem. Abstr. 52, 1219e (1958).

21. R. Kreher and W. Gerhardt. Liebigs Ann. Chem. 240 (198I).

22. M.A. McCall, J.R. Caldwell, H.G. Moore, and H.M. Beard. J. Macromol. Sci. Chem. 5, 911 (1969).

23. J.M. Timki, S.S. Moore, D.M. Walba, P.C. Hiberty, and D.J. Cram. J. Am. Chem. Soc. 99, 4207 (1977)

24. R.M. Beesley, C.K. Ingold, and J.F. Thorpe. J. Chem. Soc. 107, 1080 (19l5).

25. C.K. Ingold, J. Chem. Soc. 119, 305 (1921); C.K. Ingold. J. Chem. Soc. 119, 951 (1921).

26. N.L. Allinger and V. Zalkow. J. Org. Chem. 25, 701 (1960).

27. B.L. Shaw. J. Am. Chem. Soc. 97, 3856 (1975).

28. P.J. Duggan and P.F. Gordon. Eur. Pat. Appl. Ep. 155780 (1985); Chem. Abstr. 105, 72642 (1987).

29. M.J. Cook, A.J. Dunn, S.D. Howe, A.J. Thomson, and K.J. Harrison, J. Chem. Soc. Perkin Trans. I, 2453 (1988).

30. N. Kobayashi, T. Ashida, and T. Osa. Chem. Lett. 2031 (1992).

31. N. Kobayashi, Y. Kobayashi, and T. Osa. J. Am. Chem. Soc. 115, 10994 (1993).

32. T.R. Janson and J.J. Katz. In The porphyrins: physical chemistry, Part B. Edited by D. Dolphin. Academic Press, New York. 1979. p. 1

33. W.O. Siegl. J. Heterocycl. Chem, 18, 1613 (1981). 